\title{
Subprime Crisis and Board (In-)Competence: Private vs. Public Banks in Germany
}

\author{
HARALD HAU \\ MARCEL THUM \\ CESIFO WORKING PAPER NO. 2640 \\ CATEGORY 7: MONETARY POLICY AND INTERNATIONAL FinanCE \\ MAY 2009
}
An electronic version of the paper may be downloaded
- from the SSRN website:
- from the RePEc website:
- from the CESifo website:
www.SSRN.com
www.RePEc.org
www.CESifo-group.org/wp




\title{
Subprime Crisis and Board (In-)Competence: Private vs. Public Banks in Germany
}

\begin{abstract}
We examine evidence for a systematic underperformance of Germany's state-owned banks in the current financial crisis and study if the bank losses can be traced to the quality of bank governance. For this purpose, we examine the biographical background of 593 supervisory board members in the 29 largest banks and find a pronounced difference in the finance and management experience of board representatives across private and state-owned banks. Measures of "boardroom competence" are then related directly to the magnitude of bank losses in the recent financial crisis. Our data confirms that supervisory board (in-)competence in finance is related to losses in the financial crisis. Improved bank governance is therefore a suitable policy objective to reduce bank fragility.
\end{abstract}

JEL Code: G2, G21, G3, G32.

Keywords: governance, supervisory boards, banking, financial crisis.

Harald Hau

INSEAD

Department of Finance

Boulevard de Constance

77305 Fontainebleau Cedex

France

harald.hau@insead.edu
Marcel Thum

Faculty of Business and Economics

TU Dresden

01062 Dresden

Germany

marcel.thum@tu-dresden.de

April 13, 2009

Paper prepared for the 49th Panel Meeting of Economic Policy in Brussels.

We thank Madlen Arnhold, Frank Kapol and Johannes Steinbrecher for their comprehensive research assistance. We thank Oliver Burkart, Jean Dermine, Marcus Dittrich, Denis Gromb, Christian Lessmann, Gunther Markwardt, Myron Slovin, Marie Sushka, David Thesmar, Frank Westermann and two anonymous referees for helpful comments on a first draft. 


\section{Introduction}

The U.S. subprime crisis had a dramatic effect on the solvency of state-owned German banks. Four fully or partly state-owned banks had to be rescued at the expense of the tax payer: WestLB, IKB Deutsche Industriebank, Sachsen LB, and Bayern LB. In this context, Wolfgang Münchau, a leading business journalist, commented:

"The more interesting point is whether it is accidental that all the German banks in trouble are essentially publicly owned. [...] The episode tells us, once again, that Germany has too many banks, and in fact, too many bankers. Most of the supervisory board members of these institutions are themselves financially illiterate and do not fully understand the ins and out of investments in new financial instruments, such as CDOs or CDS. They have failed to implement proper risk management systems - something which a private bank could ill afford."1

The objective of our study is to examine both assertions, namely whether German state-owned banks indeed suffered disproportionally higher subprime-related losses than private banks and whether this could reflect differences in board competence between state-owned and private sector banks.

The answers to these questions hold importance far beyond the specific context of German banking. Worldwide, a large proportion of bank assets are still effectively state-owned. Estimates by La Porta, Lopez-de-Silanes and Shleifer (2002) suggest that on average 42 percent of the equity of the 10 largest banks in each country was state-owned in 1995 . The German banking sector with its large share of state-owned banks is in some ways typical of the worldwide distribution of control rights in banks. State-ownership in Germany and elsewhere comes with a specific governance structure in which high-level state employees and politicians exercise the monitoring function otherwise played by private shareholders or their representatives. This raises some important questions: What is the quality of such bank supervision? Does public ownership come at the price of a deficient bank management control? The economic significance of this question far transcends the German economic context analyzed here.

As a consequence of recent government sponsored bank recapitalization plans, state-ownership in banks is likely to experience a dramatic increase. Even countries like the U.S. and the U.K., where state-ownership in banks was never important, now feature a partially state-owned banking sector. Will the government seek the shareholder representation which comes with its ownership share and delegate treasury representatives and politicians to the respective bank boards? Again, a close look at the monitoring effectiveness of such state delegates seems warranted and the German experience offers an instructive case study.

The banking crisis certainly led to financial distress also among many private banks. First, we do not claim that private ownership is a sufficient condition for a bank's crisis resilience. Indeed, private bank institutions may also suffer from severe corporate governance problems. Their failure in risk control does not invalidate the hypothesis that bank governance matters. Second, equity owners generally do not have optimal incentives when it comes to risk choices. The corporate finance literature highlights that the option character of private equity may give the equity owners an incentive for excessive risk taking. In particular, equity owners profit

\footnotetext{
${ }^{1}$ The quote is taken from an article entitled "Another Landesbank bites the dust" on the website of Eurointelligence http://www.eurointelligence.com/Article3.1018+M50fcec22186.0.html.
} 
from a mean preserving increase in the dispersion of payoffs due to their limited liability. But short of actual bankruptcy, equity owners are certainly most exposed to any decrease in longrun expected payoffs. Hence, any misalignment of social and shareholder objectives may well be a second order problem compared to the corporate governance problems related, for example, to badly designed compensation systems and/or a breakdown of management monitoring related to state-ownership.

The recent financial crisis has revived the interest in issues of the stability of the banking sector. There is general agreement now - even by supervisors and standard setters themselves - that bank supervision was often too lenient and ineffective. But it is also worth recalling that such leniency may often have been the result of political lobbying of the financial industry itself. Last, but not least, the general extension of credit and leveraged finance served powerful political interests which are likely to persist in the future. ${ }^{2}$ This raises the question as to whether tough banking regulation can withstand opportunistic political behavior in the long run. The political exposure of bank supervision then calls for a more general approach to banking stability which explores additional policy measures by which banking stability can be enhanced in the presence of imperfect bank supervision. ${ }^{3}$

One such policy dimension which we examine in this article is the role of bank governance. A closer look at the data reveals that there is high variance in bank performance during the crisis. What can we learn from these performance differences? Can they be explained by the quality of bank governance? The empirical study in this paper sheds some light on these questions. Five findings can be highlighted:

1. The 29 largest German banks show a systematic underperformance of state-owned banks in the recent banking crisis. Adjusted for size, asset write-downs and losses from the first quarter of 2007 to the third quarter of 2008 are on average three times as large for state-owned banks compared to privately owned banks.

2. A close examination of the biographical background of 593 supervisory board members in the largest German banks reveals that measures of management and financial experience of the board members are systematically higher in privately owned banks compared to state-owned banks. This difference in boardroom competence is statistically highly significant and qualitatively large.

3. Bank losses during the financial crisis correlate with the financial (in-)competence of supervisory boards. A lack of competent board monitoring is therefore our leading explanation for underperformance of state banks. A causal linkage between board competence and crisis performance is confirmed by using the exogenous number of politically appointed board members as a statistical instrument for financial board competence.

4. We find no evidence for other managerial constraints related to state ownership which can account for the underperformance of state banks. For example, executive compensation is only slightly lower (by 9.5 percent) compared to private banks.

5. Higher average executive board compensation is positively correlated with bank losses contrary to what can be expected in an efficient market for managerial pay. Investment

\footnotetext{
${ }^{2}$ Reinhart and Rogoff (2008) remark that the list of leading contributors to the presidential and congressional candidates in the U.S. election is dominated by financial companies. They conclude: 'Thus it is no surprise that, during the boom, all the supposed market watchdogs were neutered. This is an international problem, not just a U.S. one.'

${ }^{3}$ The most widely endorsed policy measure in this context is the transfer of interbank trading in the OTC markets to organized exchanges with centralized guaranteed clearing. This highly sensible measure is not the focus of the current article.
} 
in executive monitoring or/and selection appear to have a higher return than more generous pay packages.

The paper is organized as follows: Section 2 provides a brief description of the German banking system, reviews the historic performance of state-owned banks and examines their performance in the recent financial crisis relative to the privately owned banks. Different hypotheses about the role of governance and crisis performance are formulated in Section 3. Section 4 undertakes a detailed study of corporate governance quality across state-owned and private banks. Here we use biographical data on 593 supervisory board members to measure supervisory board competence and monitoring ability. Section 5 examines the linkage between board quality and a bank's crisis performance. In Section 6, we explore alternative explanations for performance differences such as managerial constraints for state-owned banks and the role of executive pay in general. A summary with policy conclusions is provided in Section 7.

\section{The German Banking System and its Performance in the Subprime Crisis}

In this section, we briefly describe the basic features of the German banking system and discuss how it fared during the financial crisis. We argue that the coexistence of a private banking system and a state-owned system makes the German banking system an ideal laboratory to study the role of different governance systems for a bank's crisis performance.

\subsection{An Overview of the German Banking Sector}

German banking is characterized by the coexistence of three types of banks - commercial banks, cooperatives and public sector banks. ${ }^{4}$

First, commercial banks are corporations and operate as universal banks. In terms of total assets, domestic commercial banks account for 28.6 percent of the German banking sector (see Figure 1). Commercial banks are privately owned and private shareholder representatives sit on their supervisory boards. The German banking statistics separately lists real estate banks which are also privately owned (with a few minor exceptions) and which account for another 11.1 percent of the banking sector.

Second, cooperative banks feature a different governance structure. The equity holders usually customers of the cooperative banks - have equal voting rights independent of their equity shares. Traditionally, the 1,200 cooperative banks have a strong regional focus. To overcome the disadvantages of such a fragmented structure, the cooperative banks have founded two cooperative central banks (DZ Bank and WGZ Bank) which, among other things, carry out the investment banking for the individual and often small cooperative banks. Overall, the segment of cooperative banks has an asset share of 12 percent.

Third, German banking also comprises a large state-owned or public banking sector. It can be further divided into two types of banks according to their geographical scope. The savings banks are organized locally or regionally. These banks are owned by their respective municipalities or counties. ${ }^{5}$ The savings banks account for 13.8 percent of banking assets and typically do not engage in any international banking activities. ${ }^{6}$ For this reason, we ignore

\footnotetext{
${ }^{4}$ For a comprehensive survey of the German banking system, see Brunner et al. (2004) and Krahnen and Schmidt (2004).

${ }^{5}$ Vins (2008) analyses the political influence on the state-owned savings banks in Germany.

${ }^{6}$ By law, the 'regional principle' constrains the activities of savings banks to their home regions. Hence, regulation rather than managerial choice partly determines the allocation of financial resources.
} 
these public sector institutions in our analysis. More important for our study are the 11 major publicly owned banks that operate nationwide and engage in international banking activities. Most of these banks belong to the so-called Landesbanken which were originally founded for providing development financing in their regions and for acting as central banking institutions for the local savings banks. Over time, however, the Landesbanken have developed into universal banks that engage in large-scale (international) lending in direct competition with the private banks. Their share of banking assets is 21 percent. In addition to the Landesbanken, there are several special purpose banks (among others, $\mathrm{KfW}$ and $\mathrm{IKB}^{7}$ ) which are directly or indirectly owned by the federal or state governments (with a few minor exceptions). Overall, the public sector banks account for 46 percent of all assets in German banking.

\section{Figure 1: Asset Shares in German Banking}

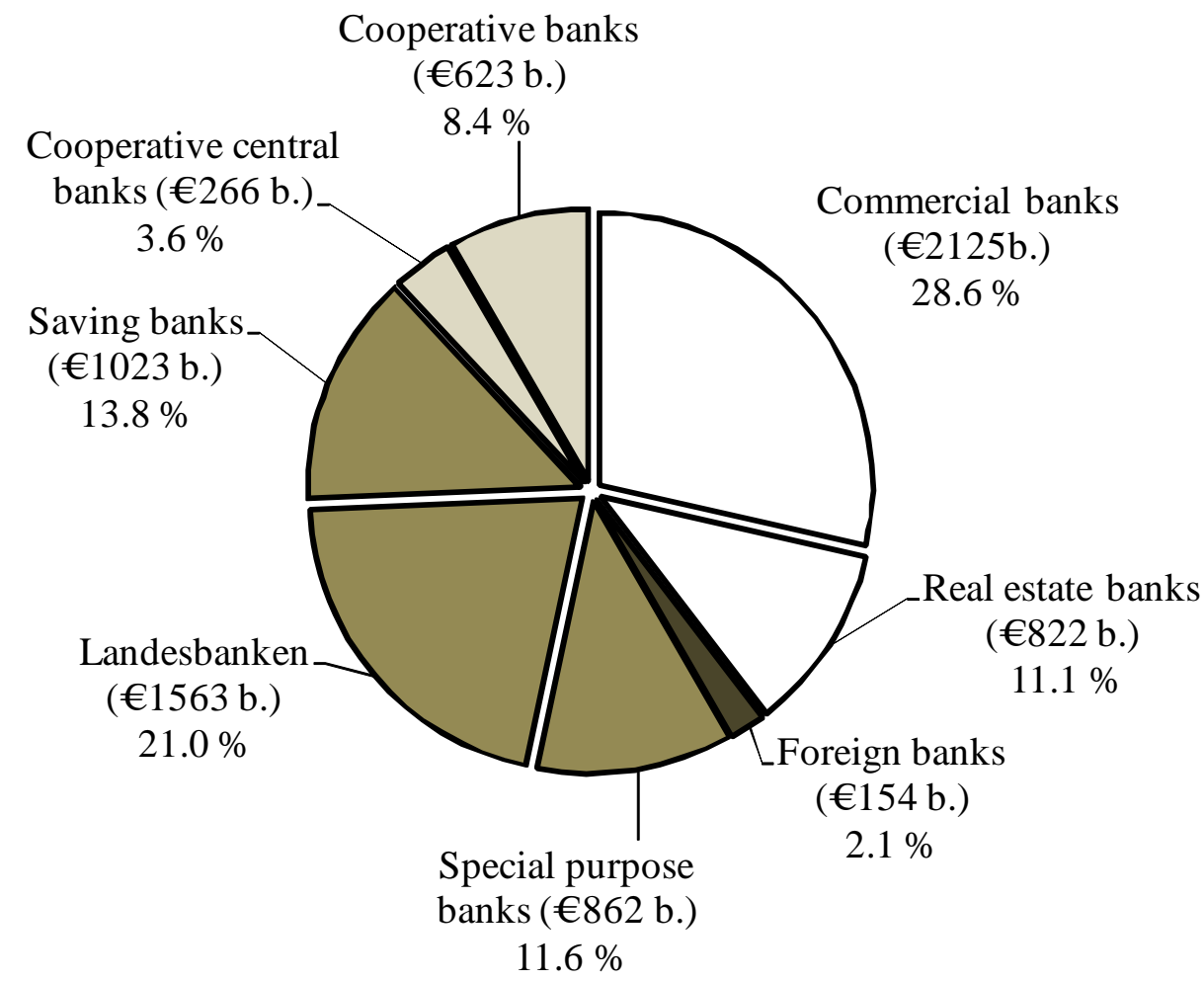

Note: Asset shares are measured by total assets. Savings \& loans are excluded as the bank statistic allows no attribution to public and private ownership. All data refer to January 2008.

Source: Deutsche Bundesbank, Bank Statistics 3/08

Foreign banks play only a minor role in German banking. In Figure 1, the 2.1 percent asset share of foreign banks captures only those banks that operate with legally non-autonomous branches in Germany. Legally autonomous subsidiaries are counted among the domestic banks. However, even if the subsidiaries of foreign banks are included, Germany is among the countries with the lowest share of foreign banks in Europe. The foreign asset share - measured by the ratio of total assets of foreign banks to total assets of all banks in a country - amounts to little more than 10 percent. Among the EU countries, only Sweden has a lower foreign asset share [see ECB (2008, Tables 2, 11 and 13)]. This aspect makes our study in bank performance across governance structures a relatively clean experiment as confounding effects of foreign ownership are largely irrelevant.

\footnotetext{
${ }^{7}$ IKB's largest shareholder is the state-owned bank KfW. After major losses in international financial markets, the KfW first had to increase its share from 38 to 91 percent and later sold the IKB to Lone Star in October 2008.
} 
Apart from a very low market penetration by foreign banks, the German banking sector also stands out by a large market share of state-owned banks. The latter aspect provides us with a relatively large sample of public sector banks for our performance study. Several countries such as Austria, France and Italy have significantly reduced public ownerships in their banking systems in recent years. Figure 2 provides some information on the market share of publicly owned banks in selected European countries. The data taken from La Porta, Lopez-de-Silanes and Shleifer (2002) refer to the year 1995 and describe the share of the assets of the top 10 banks in a given country that is owned by the government. The World Bank data use a different classification. Here the market share is loosely defined as the ratio of assets of publicly owned banks to total assets in the banking sector. The data refer to the years 1999 and 2005. Compared to other highly industrialized economies, the exceptionally large involvement of the public sector in German banking has become particularly evident in recent years.

\section{Figure 2: Asset Shares of Publicly Owned Banks in Selected European Countries}

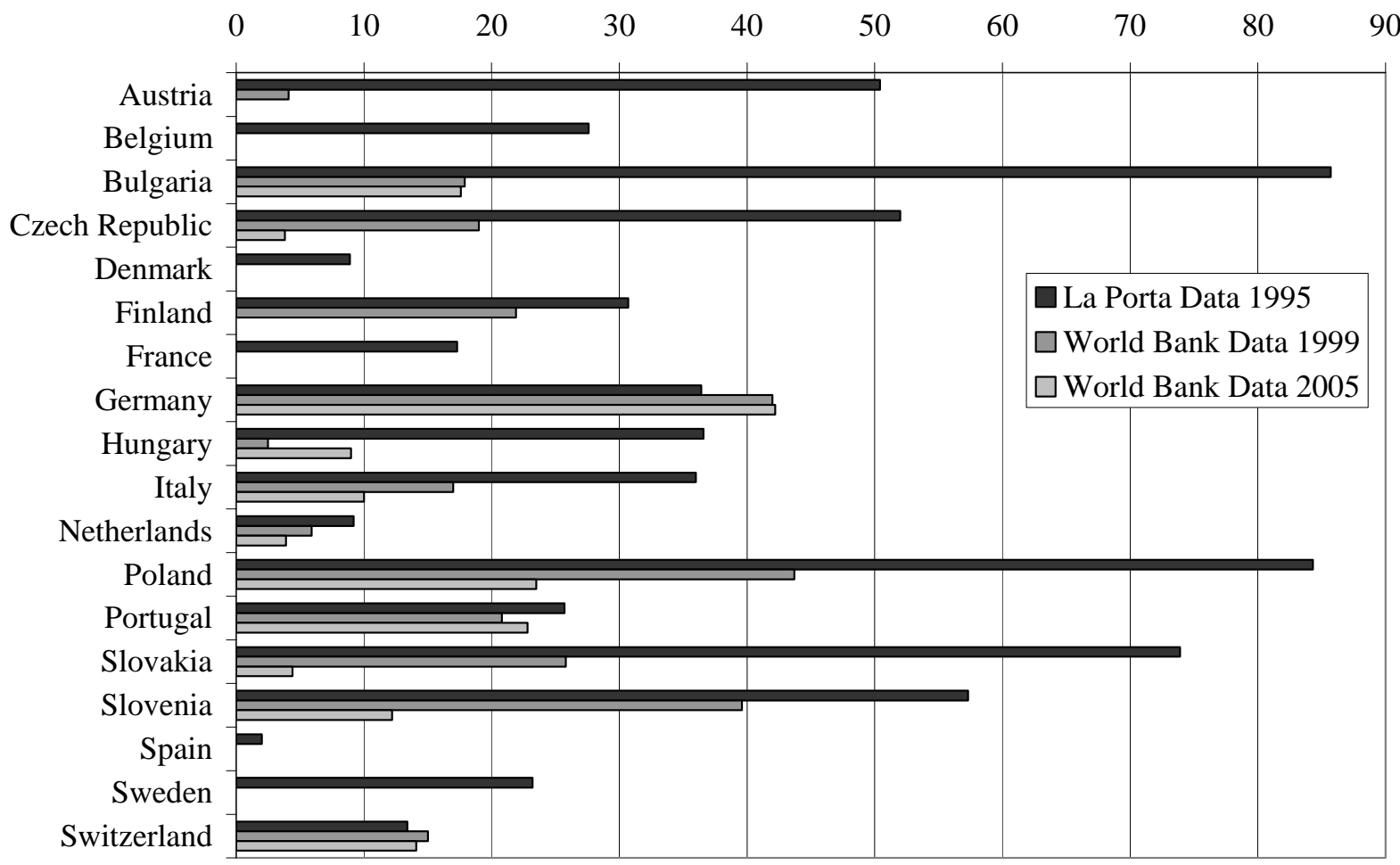

Note: The figures for Germany are not directly comparable with the public sector share in Figure 1 . Figure 1 excludes savings \& loans and counts all assets of special purpose banks as publicly owned.

Sources: La Porta, Lopez-de-Silanes and Shleifer (2002), World Bank - Bank Regulation and Supervision Database (2000 and 2007), http://econ.worldbank.org/

\subsection{Public Bank Performance Prior to the Current Banking Crisis}

Do public banks in Germany show signs of poor financial performance even prior to the current banking crisis? The history of financial turmoil surrounding these banks suggests so. The IMF (2006) calculates that the Landesbanken received capital injections of almost $€ 9$ billion from 1991 to 2005 from their public owners (Table 1). Many of these capital injections were needed to replenish the capital base after large losses. ${ }^{8}$

\footnotetext{
8 Sinn (1999) delivers a critical analysis prior to the abolishment of some special privileges
} (“Gewährträgerhaftung” and “Anstaltslast”) for German state banks. 
The West LB, which is owned by the state, the municipalities and the savings banks of North Rhine-Westphalia, provides an illustration. Soon after its foundation in 1973, the bank lost DM 300 millions in foreign exchange trading. During the Russian crisis of 1998, the bank made headlines again due to massive losses from non-collateralized investments. In 2003, the West LB faced its most severe crisis so far when it lost almost $€ 4$ billion. During the current financial crisis, the West LB initially announced (moderate) write-downs. In November 2007, the bank was no longer able to get short-run financing for its long-run real estate loans. The owners had to agree on a capital injection of $€ 2$ billion. A few weeks later, the capital needs turned out to be even larger and the owners had to increase their capital guarantees to $€ 5$ billion so that the West LB could transfer its risky business of $€ 23$ billion to a special purpose vehicle. Another example involved the LB Berlin, which was merged into the holding company Bankgesellschaft Berlin in 1994. Bankgesellschaft Berlin engaged in large-scale real estate speculation over the period 1994 to 2001 and had to be saved by a capital injection of $€ 1.7$ billion and a loan guarantee amounting to $€ 21.6$ billion.

The IMF (2006, 76) judgment on the historic performance of German state-owned banks is rather harsh: "LBs [Landesbanken] have been providing poor financial returns, resulting in average opportunity costs to taxpayers equivalent to about 1/4 percent of GDP annually since the early 1990s.”

\subsection{Public and Private Bank Performance in the Current Banking Crisis}

The most recent banking crisis provides a controlled experiment which allows a more systematic performance comparison of state-owned and privately owned banks.

The German Council of Economic Experts [Sachverständigenrat (2008)] calculates a total write-down of \$ 48.8 billion for German banks. These data were collected from press articles on the interim reports of major German banks (January 2007 until May 2008). The breakdown according to bank type paints a striking picture. Even though the asset share of the Landesbanken is only 21 percent, these state-owned banks account for 43 percent of the total write-downs. Including other state-owned banks does not change the picture. The share of all public banks in total assets amounts to 42 percent according to the World Bank Statistics. In the financial crisis, however, they account for 64 percent of all write-downs in the German banking system.

The current paper extends the study undertaken by the Council of Economic Experts both in the sample size and the time period covered. We select all German banks with total assets above $€ 40$ billion in January 2007. This sample consists of the 29 largest German banks with bank assets above $€ 40$ billion, of which 13 are state-owned (for the majority of shares) and 16 are private banks. For every bank, we investigate crisis related losses for the period from the first quarter of 2007 to the third quarter of 2008 that were published until December 31, 2008. For this purpose we study the news wires and press releases about asset write-downs and about losses from operating and investment activity. Furthermore, all income statements over the 7 quarters were separately examined as a cross-check and to capture losses not reported in press releases. Typically, quarterly income statements reported crisis related bank losses in the footnotes and/or appendices. For 4 of the 29 banks, documentation of bank losses and asset write-downs was missing or so incomplete that we could not establish a quantitative performance measure. These banks were excluded from any performance regression. ${ }^{9}$ Table 2 reports the bank losses for the 25 banks for which we could calculate losses in the financial crisis of 2007-2008. Quarterly losses were simply added up without discounting. We would have preferred to rely solely on annual reports which are audited by certified accountants.

\footnotetext{
${ }^{9}$ These banks are Depfa Deutsche Pfandbrief Bank, Essenhyp, NRW Bank and WL Bank,
} 
However, due to the time constraints of this study and the delay in the publication of annual reports, we use quarterly statements complemented by press releases. Interviews with accounting experts confirmed that some banks may not promptly update the entire accounting data. Some risk evaluations are too complex to be carried out on a quarterly basis. In times of a crisis, this can lead to delayed information about losses. Banks may also concentrate their write-downs in one quarter for reasons of strategic news management. However, interviews with accounting experts reassured us about the second-order magnitude of these shortcomings: Private banks tend to dispose of more timely and more comprehensive accounting data. Any reporting bias due to delayed reporting should tend to underestimate the losses of state banks.

Unfortunately it is also not possible to disaggregate the losses further into specific subcategories such as U.S.-mortgage related losses or losses related to bank failure (Lehman Brothers, Icelandic banks, etc). Also a more detailed use of balance sheet positions is prevented by two factors. First, some banks in the sample use 'mark to market' accounting for most of 2007 and 2008, while others continued to publish income statements under the 'historic value accounting'. Second, in the course of the banking crisis in the fall of 2008, 'mark to market' was suspended by some institutions, which further complicates the picture.

Table 2 summarizes the key financial statistics for each of the 29 sample banks. Three measures of bank size are reported. The total asset value [column (3) in Table 2] and the tier 1 capital [column (5)] of each bank at the end of 2006 and 2007 are averaged to obtain size proxies. Similarly, we average the book value of equity [column (4)] at the end of 2006 and 2007 to obtain a measure of equity capital. This allows us to calculate a leverage proxy [column (6)] as the ratio of total asset to book equity. Some of the regressions use (log of) leverage as a control variable in the performance regressions. To control for bank size, we normalize the losses by total assets and by equity capital [columns (8) and (9)]. The last rows in columns (8) and (9) illustrate the significantly higher losses in state-owned banks compared to private banks. The Spearman rank test shows that their respective performance difference is significant at the 1 percent level. This is an exact test (valid for small samples) which makes no distributional assumptions.

Next, we report OLS regressions to examine further whether state-owned banks had a disproportional share of the bank losses in the recent financial crisis. Summary statistics on all regression variables are provided in Table 3. Regression specification (1) in Table 4 uses the (log of the) bank losses normalized by bank assets as the dependent variable. Regression models (2) to (5) consider the (log of the) bank loss as the dependent variable. Regression controls here are bank size proxied by the log of total assets or by the log of tier 1 capital. We have also included bank leverage defined as the log ratio of bank book equity to total assets. The coefficient of interest concerns the dummy variable which marks state-ownership with one and which is zero for privately owned banks. In each of the five specifications, the dummy variable marking the state-owned banks shows a positive value significant at the 3 percent level. As a robustness check, we calculated (but do not report) $t$-values in Table 4 and all following regressions under bootstrapping and find that the statistical significance of the results remains unchanged. The magnitude of the coefficient of 0.842 to 1.208 implies that the losses of the state-owned banks are $132 \%$ to $235 \%$ (= $100 \times \exp (0.842)-100$ to $100 \times \exp (1.208)-$ 100) higher than for their private counterparts. This constitutes an economically large difference in the crisis performance between private and state-owned banks.

What accounts for the poor historic performance of state-owned banks and their statistically significant underperformance in the recent financial crisis? The following section develops some plausible hypotheses about the performance differences. 


\section{Hypotheses about Bank Governance and Crisis Performance}

The systematic performance shortfall of state controlled banks in the current financial crisis calls for an explanation. Given that all state banks share by definition a common type of owner, corporate governance is a natural starting point.

A common argument in the economic literature against state ownership is that the state is a very weak and ineffective principal. This may be reflected by board members who owe their mandate to political connections rather than financial competence. But what is the linkage between supervisory board composition and crisis performance? To clarify causal relationships, it is helpful to conjecture different channels. We highlight 5 different hypotheses:

\section{H1: Strong Monitoring Hypothesis}

Board competence matters for the quality of a bank's investment strategy. Poorly monitored CEOs and management teams can pursue investment strategies of higher risk and low riskadjusted return. The high risk strategies get exposed during a financial crisis and generate higher losses.

\section{H2: Gambling for Profitability Hypothesis}

Banks with a viable business model reflected in poorer operating performances pursue riskier investment strategies. These improve profits in normal times at the risk of higher losses during a crisis.

\section{H3: Weak Monitoring Hypothesis}

Board competence matters indirectly through the selection and appointment of a capable CEO and his top management team. Less competent supervisory boards chose more competent management teams, which leads to better operating performance.

\section{H4: Managerial Constraints Hypothesis}

State-owned banks operate under pay constraints for the CEO and top management. In a competitive labour market for talent, they end up with the worst managers and therefore have worse operating and crisis performance.

\section{H5: Efficient Executive Pay Hypothesis}

Even in the absence of pay constraints, better paying institutions might be able to attract better managers. Hence, higher executive pay for a bank's top management comes along with better risk management and better crisis performance.

The strong monitoring hypothesis $\mathrm{H} 1$ assumes a direct role of the supervisory board in constraining and/or improving the risk choices of management. Poor competitiveness has recently been evoked as a motivation for excessive risk taking by state-owned bank as expressed in hypothesis H2. Hellwig (2008) reports that state banks were "caught up in a yield panic" in a time when their intermediation and interest rate margins were low. Industry observers point out that state-owned banks did not have a viable business model based on some competitive advantage [Münchau (2008)]. This might have put greater pressure on state banks to seek higher yields in higher risk. But it is important to note that the 'gambling for profitability hypothesis' as such cannot explain the underperformance of state banks. The hypothesis only explains underperformance during the crisis with previous underperformance in operational activity without specifying where the latter originates in. While plausible, it 
needs to be combined with the 'weak monitoring hypothesis' to provide a full explanation. H2 and $\mathrm{H} 3$ are therefore complementary. The weak monitoring hypothesis does not require the same level of supervisory board involvement as its 'strong' counterpart H1 and therefore seems more in line with anecdotal evidence about actual governance practices. Such anecdotal evidence suggests that supervisory boards typically do not scrutinize the investment strategy of the executive board.

Both $\mathrm{H} 1$ and the combination of $\mathrm{H} 2$ and $\mathrm{H} 3$ imply a correlation between supervisory board competence and state ownership on the one hand and between board competence and crisis performance on the other hand. We investigate both issues empirically in sections 4 and 5, respectively. $\mathrm{H} 2$ presupposes operational underperformance of state-owned banks. This issue is further investigated in Section 6.1.

Hypothesis $\mathrm{H} 4$ presents an alternative (board independent) explanation for underperformance of state-owned banks. Here it is state-ownership itself rather than governance deficiencies which account for the poor crisis performance of state-owned banks. The hypothesis claims that state-owned banks are constrained in the remuneration of their executives and, therefore, attract less competent managers. We test this alternative hypothesis by examining top executive salaries in state banks relative to private banks in section 6.2.

Finally, we examine the role of executive pay levels in the crisis. The efficient executive pay hypothesis states that executive compensation simply reflects the value of scarce competencies. Higher paid executive management teams should then be able to undertake better investment strategies. This will pay off in particular in the moment of reckoning which is the financial crisis. The respective evidence is discussed in Section 6.3.

\section{Supervisory Board Competence across State-Owned and Private Banks}

Both the weak and the strong monitoring hypothesis conjecture that supervisory board competence matters. The selection of talented executives and/or their effective monitoring requires that the relevant competencies are available in the supervisory board. In particular, the members of the supervisory board may need a comprehensive understanding of modern financial markets. Testing such a proposition requires us to produce proxy variables for board competence. Secondly, we need to document that these measures indeed show a competence gap between the boards of state-owned and private banks.

\subsection{Related Research}

Much of the corporate finance literature has focused on formal rather than qualitative measures of boardroom composition, mostly board independence, board size and directors' stock ownership. The evidence on the role of board independence as measured by the number of outside directors remains mixed. Some studies show no performance effect for board independence [Bhagat and Black (2002), Hermalin and Weisbach (1991), Klein (1995), MacAvoy et al. (1983), Mehran (1995)], while others identify a significant positive performance effect of board independence [Baysinger and Butler (1985), Schellinger, Wood and Tashakori (1989)]. Board size on the other hand is generally found to be negatively correlated with performance measures [Brown and Maloney (1999), Yermack (1996)]. With a large supervisory board, the free-riding of individual board members may lead to a low monitoring effort. There is also evidence that director ownership in a firm correlates with better performance measured by Tobin's Q [Hermalin and Weisbach (1991), Morck, Shleifer and Vishny (1988)]. 
Two recent papers look at more qualitative measures with respect to board composition. Güner, Malmendier and Tate (2008) examine the role of financial board expertise and find that it matters in the presence of conflicts of interest between contracting parties. In contrast to our paper, they analyse the role of financial expertise in the boards of non-financial firms. Another important qualitative dimension of supervisory competencies is the industry experience of board members. Papakonstantinou (2008) shows that industry experience correlates positively with abnormal stock returns and negatively with earnings manipulation. A particularly original approach to identifying causal links between monitoring and corporate performance is taken by Becker et al. (2008). They show that the presence of rich individual shareholders on U.S. company boards improves the operating and financial performance of the firms. The authors use the density of high-wealth individuals in the proximity of the company headquarters as an exogenous instrument to eliminate reverse causality and also control for self-selection effects.

\subsection{Measures of Supervisory Board Competence}

Our own study takes a further step towards qualitative measurement of boardroom competence by focusing on a single industry - the banking sector - and by collecting an entire set of competence indicators. We focus on the 29 largest banks in Germany which exceed $€ 40$ billion in total assets (see Table 2).

To obtain a measure of the monitoring potential in the supervisory boards of these 29 banks, we define 14 different biographical criteria which proxy for boardroom competence in the context of the financial crisis. The variables capture a board member's educational background (3 indicator variables), finance experience (6 indicator variables) and management experience (5 indicator variables).

For each member of the supervisory boards of 29 banks, we collected the relevant data from publicly available sources. Most of the information could be retrieved from the annual statements and the web sites of the banks. In many cases, board members hold other prominent positions (e.g., as top executives in other firms or as politicians) enabling us to use information provided by their main affiliation. The data set was supplemented with material from biographical encyclopedia or news reports about the board members. The reference date for board memberships was January 1, 2008. In cases where deputy members are allowed on supervisory boards, we included data on both the regular member and the deputy, e.g., the prime minister of a state and the undersecretary of state.

\subsubsection{Educational Background}

We conjecture here that educational background matters for the monitoring ability of supervisory board members. This may be particularly the case in banking where judgement on a particular investment strategy often requires a high degree of financial literacy. We define three levels of educational achievement by the following 3 criteria:

- E1: Does the board member hold a Business/Economics Degree? If the answer is yes, the criterion $E 1$ is marked as 1 and 0 otherwise. It is conjectured that extensive training in economics and finance may improve the monitoring ability of supervisory board members.

- E2: Does the board member hold a MBA Degree? Some executives hold MBA degrees and these also confer on the holder a more extensive knowledge of accounting, finance and economics. 
- E3: Does the board member hold a PhD Degree in Business/Economics? A PhD degree signals advanced knowledge and a capacity for abstract economic thought, provides an easier access to the scientific literature and enables a boarder judgement on financial instruments and their risks. ${ }^{10}$

\subsubsection{Finance Experience}

Effective monitoring of bank managers may involve industry-specific knowledge which depends on experience. We distinguish 6 criteria:

- F1: Does the board member have Banking Experience? The person is considered to have banking experience if he or she has ever worked in a bank.

- F2: Does the board member have Financial Market Experience? As financial market experience we record any previous occupation related to asset market trading or investment. Financial market experience should make the board member a better monitor of investment risks. ${ }^{11}$

- F3: Does the board member have Financial Market Experience after 1990? As the human capital in financial markets depreciates over time, we also collect the information, whether the financial market experience is fairly recent, i.e., was gained after 1990.

- F4: Does the board member have Financial Market Experience in the Same Bank? A past employment in the trading or investment division of the monitored bank might procure the board member a particular information advantage and make him a more effective monitor. ${ }^{12}$

- F5: Does the board member have a U.S. Financial Market Experience? A managerial experience in oversee markets might provide the board member with better information access and possibly a better judgement on the institutional risks of the U.S. subprime market.

- F6: Does the board member have a U.S. Financial Market Experience after 1990? This is the same as criterion F5, only with the additional requirement that the experience need to have occurred after 1990.

\footnotetext{
${ }^{10}$ In cases where the exact type of doctoral degree could not be extracted from the available biographical information, we assume that every person with studies in business or economics and a doctoral degree has achieved this doctoral degree in business or economics.

${ }^{11}$ Gilian Tett (2008) suggests that the background of CEO and top management is crucial for crisis performance: '[The most successful CEOs]... have had direct career experience of trading and managing market risk. This has given them an obvious advantage in navigating the credit cycle, since they presumably know what a derivative is. Furthermore, men such as Lloyd Blankfein at Goldman Sachs or Anshu Jain at Deutsche, who have risen through trading desks, instinctively tend to view everything in terms of probabilities and risk. That is a different mindset from somebody who has previously worked as a salesman, adviser - or lawyer, such as Mr Prince [from Citybank].'

${ }^{12}$ We concede that past employment links to the same bank might also compromise the independence of the board member. Unfortunately, board member independence is not readily measureable for the German supervisory board members.
} 


\subsubsection{Management Experience}

A professional corporate management background may provide a board member with many skills which make him more effective in supervising the activities of other corporate managers. Here we define 5 criteria which could correlate with generic monitoring ability:

- M1: Does the board member have a Consulting Experience? Board members with a consulting background can typically account for a wide range of corporate experiences including financial distress. That may make them better monitors.

- M2: Does the board member have a Mid-level Management Experience? This variable captures whether a board member has ever worked as an executive independent of the management level.

- M3: Does the board member have a Top-level Financial Management Experience? It is registered whether a board member has ever worked in a top-level finance position.

- M4: Does the board member have a Top-level Financial Management Experience in the Same Bank? This is the same criterion as M3, but restricts the experience to the same bank the board member is monitoring.

- M5: Does the board member have Multiple Board Memberships? Board members who are appointed to several supervisory boards may be more experienced in monitoring the executives. ${ }^{13}$

\subsubsection{Summary Statistics}

Table 5 provides summary statistics for the 14 competence proxies for 593 board members in the 29 largest German banks. As we focus on qualitative differences in the boardroom composition of private and state-owned banks, the summary statistics are reported separately for the two types of banks. There are 215 board members in private banks and 378 board members in state-owned banks. Columns (1) to (6) concern the private sector banks and columns (7) to (12) the state-owned banks.

According to German law, a firm size dependent number of board members are worker representatives for which we report separately in columns (5), (6), (11) and (12). ${ }^{14}$ However, detailed biographical information on worker representatives on the bank board is often unavailable. Therefore, we will mostly focus on the analysis of the owner representatives. This leaves us with 139 board members of private banks and 268 board members of state-owned banks.

All competence proxies are binomial variables, where a 'one' implies that the criterion is fulfilled and 'zero' otherwise. It is useful to aggregate these binomial variables to indices of supervisory board competence. We define 4 aggregate indices of board competence:

- IE: Sum of a board member's educational indicators E1 to E3

- IF: Sum of a board member’s financial competence indicators F1 to F6

- IM: Sum of a board member’s managerial competence indictors M1 to M5

\footnotetext{
${ }^{13}$ We just capture whether a board member has additional appointments but we do not count the number of board memberships.

14 According to the so called 'Drittelbeteiligungsgesetz', a third of the board members need to be worker representatives for corporations with less than 2000 employees. Beyond this threshold, the so called 'Mitbestimmungsgesetz' applies, which requires that half of the board members are worker representatives.
} 
- IT: Sum of all competence indicators of a board member.

Summary statistics on these 4 aggregate measures of board competence are reported in the last 4 rows of Table 5 .

In addition to the 14 competence indicators and the 4 aggregate indices, we also report some statistics on the biographical background of board members. Age provides the average age of the board members. Foreign Nationality is the percentage of board members born in a nonGerman speaking country. Politically Appointed Board Members captures the case that highranking bureaucrats and politicians holding a party and/or government office become representatives in a supervisory board.

\subsection{Supervisory Board Competence in Comparison}

The difference in board competence is pronounced as is evident from a comparison of proxy means in Table 5. For example, almost 37 percent of owner representative's board members in private sector banks feature some banking experience $(F 1)$ in their curriculum vitae. In the state-owned sector this criterion is fulfilled only by 14.2 percent of the corresponding board members. The difference in financial market experience $(F 2)$ is even more pronounced at 36.7 percent versus 10.1 percent. A similar qualitative difference is registered if one focuses on experience in U.S. financial markets (F5) - arguably particularly relevant with respect to the subprime crisis. We find U.S. financial market experience for 20.9 percent of the owner representatives on the board of private banks compared to only 2.6 percent for the owner representatives in state-owned banks.

Also in the categories of education and management experience, the private banks have a lead over the state-owned banks. The board members in private banks have 30 percent more academic degrees in business and economics (E1) and twice as many doctoral degrees (E3). More than a third of the board members in private banks had a top level management position in finance in comparison to 12 percent in public banks (M3). The management experience in the same bank (M4) is almost non-existent in supervisory boards of state-owned banks.

Columns (13) to (15) report the one-sided Fisher tests for the hypothesis that the competence proxies are the same for private and state-owned banks, where column (13) concerns all board members, column (14) the owner representatives and column (15) the worker representatives. The hypothesis that board competence is equal across private and state-owned banks can be rejected for all of the 14 board competence proxies. The hypothesis is rejected at the one percent level for 11 of the 14 criteria; for the remaining three criteria (Business/Econ Degree, Consulting Experience, Multiple Board Memberships) a false rejection of the hypothesis still has a probability of less than 10 percent. Moreover, differences are also qualitatively large. The aggregate measure of finance experience $(I F)$ summing the six indicator variables $F 1$ to F6 has a mean value of 1.51 and 0.39 for private and state-owned banks, respectively. By this simple linear metric, a board member in a private bank had on average a 3 times higher competence measure than his colleague in a state-owned institution.

Figure 3 illustrates the difference between private and state-owned banks for the three competence indices plus the total index which sums all 14 criteria. To allow for a better comparison across the 4 indices, we have scaled them to a range from 0 to 10 , where 0 implies that none of the index criteria are fulfilled by a board member and 10 means he fulfils all of them. The difference between private and state-owned banks is particularly strong with respect to management and finance experience of the supervisory board members. 


\section{Figure 3: Supervisory Board Members in Private and Public Banks}

The figure shows the means for the competence indices of all private and public bank supervisory board members, respectively. To obtain better comparability across indices, each index is scaled so that values can vary over the range 0 to 10 .

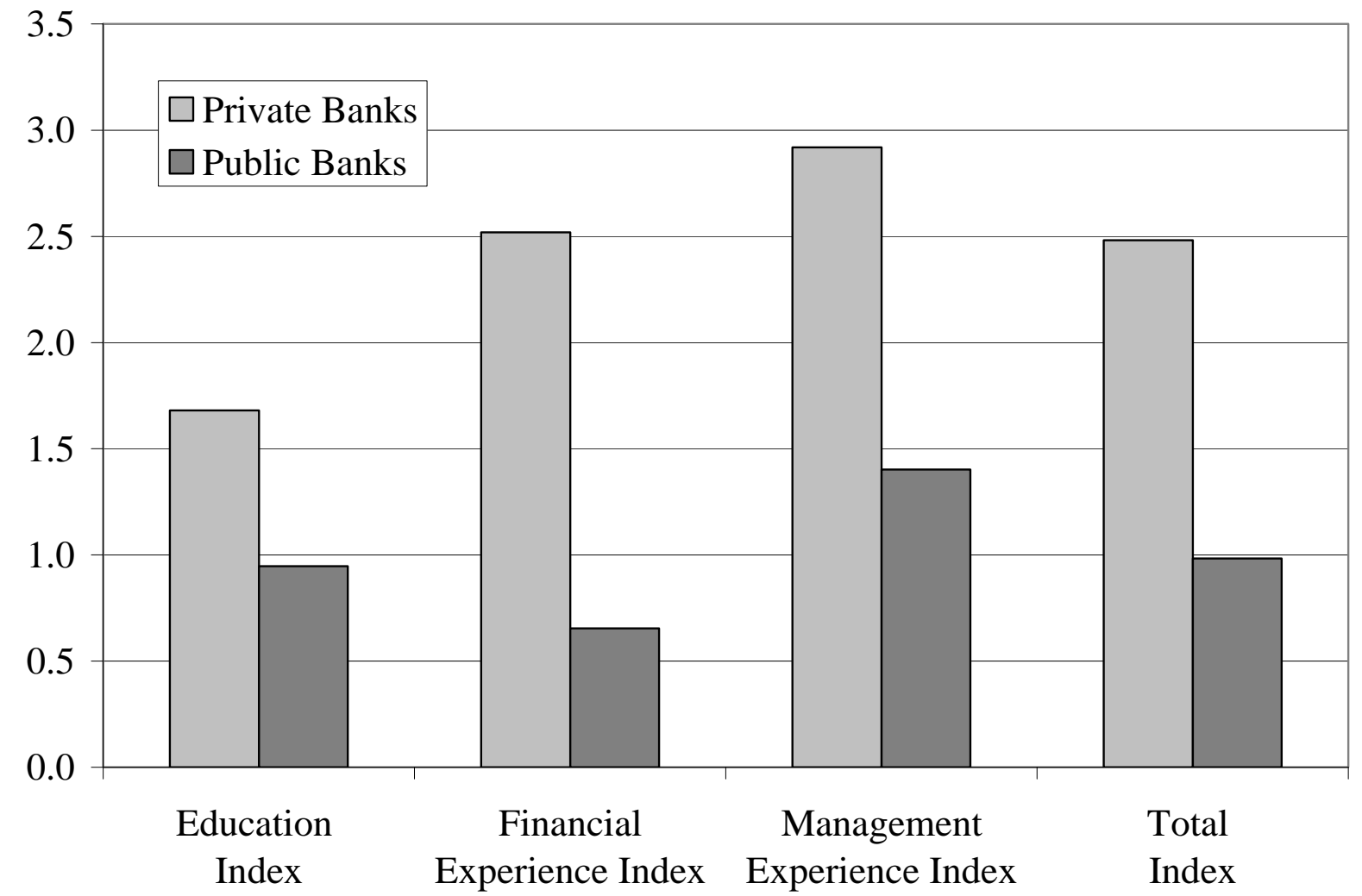

Source: Authors’ calculation

One of the potential sources of fewer competencies in state-owned banks could be the practice of having politicians and politically appointed bureaucrats as owner representatives in the supervisory boards. Most of the politically connected board members made their career in politics and in the administration but have little experience in banking and financial markets. Therefore, we also test whether the competencies of politically connected board members significantly differ from other board members. Table 6 provides the respective evidence broken down into the 14 competence criteria. Column (4) states the percentage of politically connected board members who fulfil a criteria and column (6) the same percentage for all other supervisory board members. Column (7) reports p-values for the hypothesis that both groups feature the same distribution for a given criteria. For 5 out of the 6 financial experience measures we can reject equality of the 1 percent level. Politically connected board members fare relatively good in terms of education, but less so for the management criteria. They almost completely lack financial experience.

Overall, the evidence on supervisory board composition of German banks shows a large competence gap between private and state-owned banks with respect to the management experience and financial market competence. The competence gap can largely be attributed to an appointment practice for state-owned banks which stacks the board with politicians and government employees as the shareholder representatives. 
Figure 4: Financial Market and Management Experience in the Supervisory Board

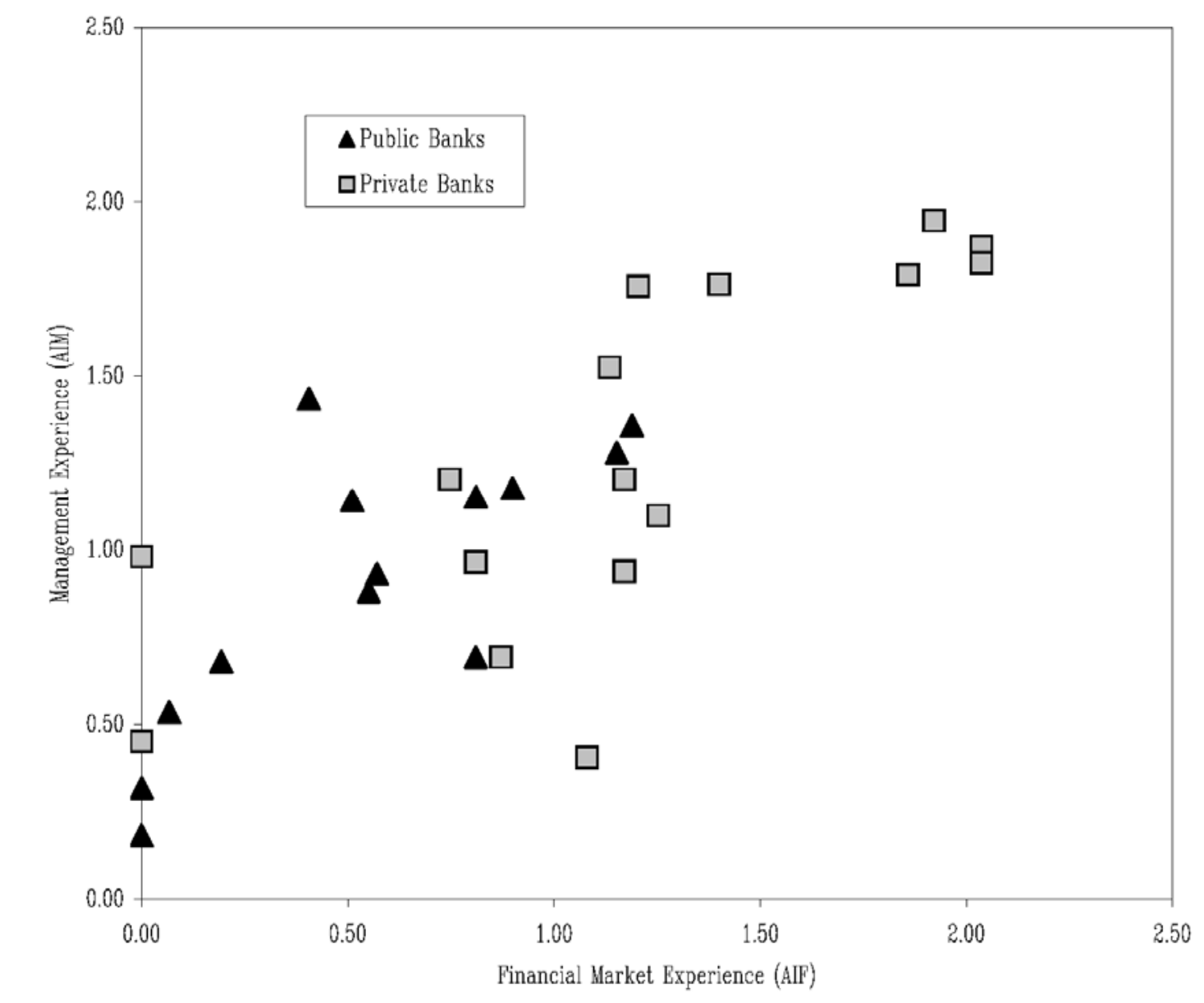

Source: Authors’ calculation

\section{The Link between Supervisory Competence and Financial Losses}

\subsection{Evidence on the Monitoring-Performance Linkage}

This section explores if the relative underperformance of state-owned compared to private banks in the recent financial crisis can be related to weak governance structures as suggested by our monitoring hypotheses ( $\mathrm{H} 1$ and $\mathrm{H} 3$ ). Executives in state-owned banks may not face any effective monitoring by supervisory boards and are therefore more prone to choose bad investments or to compensate low profitability by investing in high risk assets (H2).

As a performance measure, we use the write-downs and losses reported by the banks during 2007 and 2008 (see Section 2.3 for a detailed description of the data). To construct explanatory variables we use the board members competence indices (IE, IF, IM and IT) as defined in Section 3.2.4. For simplicity, we assume that the quality of a bank supervisory board and its monitoring ability is equal to the mean competence level of its members. To allow for a better comparison across the 4 aggregate board indices, we scale them to a range from 0 to 10 , where 0 implies that no board member fulfils any of the index criteria and 10 implies that all board members fulfil all index criteria. While board quality need not to be equal to the average skill of its member, we cannot entertain any non-linear hypothesis here for a lack of statistical 
power. We therefore settle for the most straightforward definition of board competence as the average competence of the board members.

The four measures of average board competence in their rescaled version are still not ideal regressors because of the (right-)skewedness of their distribution. In order to obtain a more normally distributed measure, we also undertake a log transformation given by

$$
A I X=\log [1+\text { scaled board mean }(I X)] \text {. }
$$

We thus obtain the (log) average board competence levels denoted as AIE, AIF, AIM, and AIT, respectively. Figure 4 shows the board competence with respect to financial experience (AIF) and management experience (AIM) in the 29 sample banks. Private banks are marked by squares, and state-owned banks by triangles. Based on the competence gap of individual board members documented in Table 5, it is no surprise that private bank boards exhibit higher average financial and management competence. We also note that the board indices for management and financial market experience are correlated across the 29 banks. Supervisory boards with higher financial competence generally feature more management experience.

\subsubsection{Explaining Relative Bank Losses}

Any comparison of losses related to the financial crisis has to account for the size of a bank and its balance sheet. This suggests that write-offs need to be standardized to make them comparable. As a suitable measure of normalization we use banks total assets. The baseline regression, therefore, consists of a simple OLS specification:

$$
\log \frac{\text { Losses }_{i}}{\text { Total Assets }_{i}}=\alpha_{0}+\alpha_{1} \text { AIX }_{i}+\mu_{i},
$$

where $A I X_{i}$ denotes one of the four board competence indices. Table 7 reports the OLS coefficients for the four aggregate indices, namely the board's average educational achievement $(A I E)$, its average financial experience $(A I F)$, its management experience (AIM) and its total experience measure (AIT). The average educational achievement, the management experience and the total experience measure do not show a statistically significant correlation with bank losses. However, a board's average finance experience is significant at the 5 percent level. We also note that the estimated coefficient has a large economic significance. The standard deviation for finance competence $(A I F)$ across banks is 0.428 . Hence, a one standard deviation deterioration in a board's finance competence implies $59 \% \quad(=$ $100 \times \exp (1.083 * 0.428)-100)$ increase in the ratio of bank losses to total assets.

Figure 5 illustrates this linkage between financial board competence and bank losses by plotting the latter against the former. Banks with financially competent supervisory boards exhibit lower losses. Figure 5 also shows again the pronounced differences between private and state-owned banks. The higher financial competence in private banks boards goes along with lower losses. Differences in board competence are therefore very coherent explanation for the pronounced underperformance of state-owned banks documented in section 2.3. 


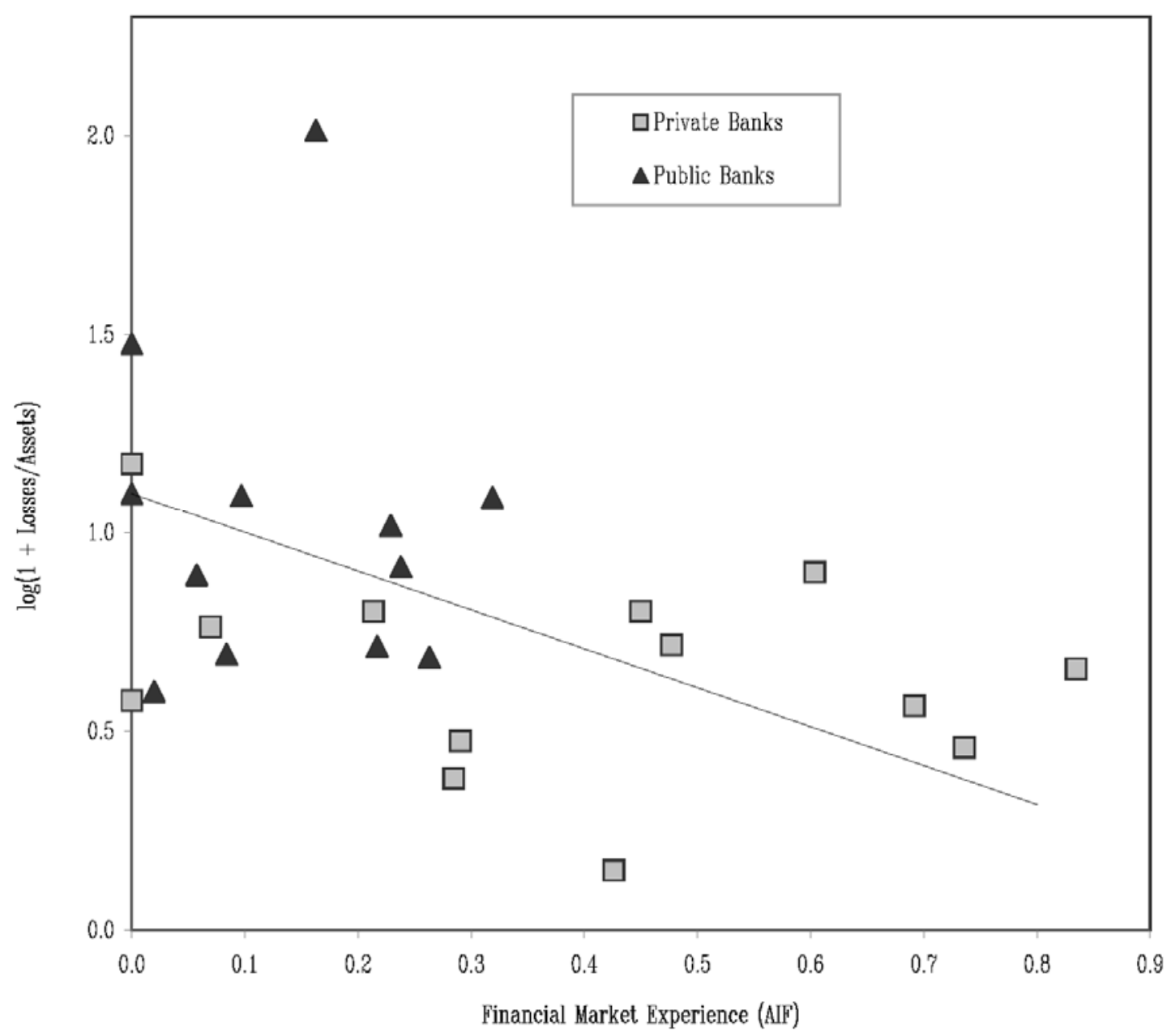

Source: Authors’ calculation

\subsubsection{Explaining Absolute Bank Losses using Size Controls}

An alternative regression specification consists in taking (the log of) the bank losses as the dependent variable. In this case, we need to control for bank size with a separate independent variable which controls for bank size. We use the log of the total assets at the end of 2006 and 2007 and the $\log$ of tier 1 capital as alternative size controls. Table 8 reports the OLS regression results for the extended specification,

$$
\log \left(\text { Losses }_{i}\right)=\alpha_{0}+\alpha_{1} \text { AIX } X_{i}+\alpha_{2} \log \left(\text { Bank Size }_{i}\right)+\mu_{i},
$$

where we control for the banks size instead of scaling by it. The results are qualitatively similar to those obtained in the baseline specification. The index for finance competence (AIF) is statistically significant at the 5 percent level; the other indices are insignificant at the standard levels. The coefficients are again qualitatively large: In the case of total assets as a size control [column (3)], a one standard deviation decrease in financial competence of the supervisory board implies a 69\% (= 100×exp(1.224*0.428)-100) increase in bank losses.

As expected bank size measured by (log) total assets is also highly significant for explaining absolute (log) bank losses with an estimated coefficient around 1. Bank losses are therefore 
approximately linear in bank size. The tier 1 capital as alternative size control is also highly significant and exhibits a coefficient slightly above 1 indicating that losses increase more than proportionally with bank size. We also verified that the above regressions are robust to the inclusion of leverage as an additional control variable. Additional leverage controls did not qualitatively change the results. The extended specification features a much higher adjusted Rsquared of 54 percent for specifications (3) and of 70 percent for specification (7) compared to only 15 percent in the corresponding specification reported in Table 7. However, the considerably higher explanatory power in Table 8 is largely due to the size variables (log of) total assets, which was previously used to scale the dependent variable, and (log of) tier 1 capital.

We also asked which of the 6 financial experience indicators for board members matters most for a bank's crisis performance. But under the constraint of a very small sample, such disaggregation did not produce any clear insights. We were not able to reject the null hypothesis that all 6 indicators matter equally. A more disaggregate approach requires a larger bank sample and more statistical power.

\subsection{Endogeneity in the Monitoring-Performance Linkage}

The statistically and economically significant linkage between measures of supervisory board competence in finance and bank losses reported in Tables 7 and 8 represent a correlation and not necessarily a causal relationship. So-called endogeneity of the board composition is a major issue for any corporate governance study. Performance difference between corporations may be driven by other factors which also drive board composition. For example, a bank CEO may pursue an investment policy without a proper risk control. Such a high-risk investment strategy may be in line with his pay incentive, or serve to disguise deficient operating performance in other areas of the bank's business. Such a CEO has a particular interest in the appointment of supervisory board members who do not scrutinize his investment policy. If the CEO can influence board appointments, as is generally the case, a supervisory board with low monitoring ability should result endogenously. The implied correlation between bank losses and a low competence index then reflects CEO's ability to manipulate board composition.

Recent research on board composition also shows that corporate boards are often dominated by particular networks related to the educational or professional background of the network members [Bertrand et al. (2008), Kramarz and Thesmar (2008)]. The large representation of politicians and bureaucrats on the state-owned bank boards may therefore have indirect effects on the choice of co-opted board members. Unlike in studies on the board composition of private sector corporations, we can clearly identify state-ownership as an exogenous determinant of board composition and board competence. Important exogenous drivers of board composition should mitigate the relative importance its endogenous determination and also generate more sample heterogeneity with respect to board composition.

A statistical strategy of controlling for endogeneity is to use instrumental variables which capture exogenous aspects of board composition. As shown in Section 4 of the paper, board composition of state-owned banks is largely conditioned by ownership structure. State-owned bank feature a large number of politically appointed board members and we can assume that the percentage of political representatives may be outside the influence of the CEO. At the same time, the percentage of political board appointments correlates (negatively) with board competence, making it a good 'instrument'. Also the public ownership status itself cannot be influenced by the CEO. This suggests two instruments, namely the percentage of political representatives and a dummy for state-ownership. 
Table 9 reports the same regressions as Table 8, except that the competence index is now instrumented. This should eliminate any reverse causality which may result from the CEO's ability to manipulate board composition. The last line in Table 9 reports the F-statistics for the first stage regression, which shows that both variables are reasonable decent instruments for the different board competence indices (except education) in line with the evidence in Table 6. The point estimates for the IV coefficients are again negative, and according to a Hausman test statistically not different from the corresponding OLS coefficients. The statistical significance level of the financial competence index in specifications (3) and (7) is now 1 percent and 5 percent, respectively. Overall, these results imply that the negative association of bank losses and supervisory board competence reflects causality running from board competence to bank performance and not in the reverse direction.

Does state-ownership induce other endogenous differences in the bank loan policies relative to private sector banks? Two effects are particularly plausible: First, research on Italian stateowned banks has shown a loan preference towards local investment projects where the political party of the board representative had strong election results [Sapienza (2004)]. This effect is hardly surprising if politicians on a bank board influence a bank's investment policy. However, such a 'home or voter bias' can hardly explain excessive investments by German banks in the U.S. mortgage market. The endogenous home bias effect should induce ceteris paribus lower subprime related losses for state-owned banks.

A second plausible investment bias of state-owned banks concerns their risk aversion. Political board representatives may see employees as part of their constituency. The interest of the employees is to avoid excessive risk taking similar to bond holders. A greater concern of stateowned banks for employee interests should bias their investment policy against any strategy which may 'wreck the ship'. ${ }^{15}$ In summary, endogenous differences in the loan policy of stateowned banks are plausible, but they should bias results against finding financial losses concentrated in the state-controlled part of the banking sector.

\section{Distinguishing Alternative Hypothesis about Performance Differences}

\subsection{Bank Governance Channels}

The evidence presented so far suggests that supervisory boards stacked with political appointees could not effectively exercise their monitoring role. Deficient governance could have had dramatic consequences through two different channels. First, deficient bank governance implied that CEOs and bank managers were free to pursue bad investment strategies in line with short-term pay incentives. We called this the strong monitoring hypothesis (H1). It assumes that board quality matters directly for the quality of a bank's investment strategy. It requires a relatively high influence of board members on the corporate decision process. A second channel might operate more indirectly. Competent supervisory boards select a competent bank leadership which improves operating performance (H3). Improved competitiveness avoids 'gambling for profitability' strategies which underlie disastrous performance during a financial crisis. Both governance channels are not mutually exclusive. The gambling for profitability hypothesis (H2) provides a plausible explanation for the relative larger losses of state banks if we find evidence for a corresponding shortfall in operating performance prior to the crisis. It is therefore interesting to compare the operating

\footnotetext{
15 The executives of state banks may also pursue an excessively risky strategy to disguise low operating profits. Such excessive risk-taking, however, is part of the "gambling for profitability" hypothesis and is discussed in Section 6.1.
} 
performance across state and private banks and also relate them to our measures of board competence.

Table 10 reports regression results for three different measures of operating performance. We examine alternatively the annual return on book assets, the return on book equity, and the per capita profits defined as the ratio of annual operating profits and the number of bank employees. ${ }^{16}$ Whenever available, this operating data was collected for the pre-crisis period 1998-2006. By all three measures, the private banks show on average a better operating performance as shown in columns (1), (4) and (7). The performance difference is economically large as a comparison of the dummy variable (capturing the lower performance of state banks) and the constant term shows. State-owned banks have on average a 36\% lower return on book assets, and a $27 \%$ lower return on book equity. However, the annual profit variability is very high so that these differences are not statistically significant at conventional confidence levels. ${ }^{17}$

Per capita profits reported in columns (7) to (9) may represent the most accurate measure of operating performance. For private banks the operating profits per bank employee averaged $€$ 200,000 for 1998-2006. By contrast, average profitability in the state banks is only $€ 40,000$ per employee [see column (7)]. ${ }^{18}$ The negative correlation between state ownership and operating profitability is again economically large, but statistically not significant. Column (8) relates operating performance directly to financial board competence (AIF). Here we find a statistically significant relationship in spite of the small sample size. An improvement of financial board competence by one standard deviation (0.428) is related to improvement in per capita profits by $€ 0.181$ million $(0.423 * 0.428)$.

The statistical nexus between financial board competence, operating performance and crisis losses underline the plausibility of the gambling for profitability hypothesis (H2). The banks with the least competent supervisory boards show the weakest operating performance and this might have created a pressure to compensate operational underperformance with higher levels of risk taking. In an efficient financial market, higher levels of market risk are systematically compensated by higher expected returns. But bank investment in illiquid mortgage securities may be far from this efficient market benchmark and could therefore combine high levels of market risk and low expected returns due to default risk.

Better executive monitoring in private banks can be facilitated not only by more competent boards, but also by public trading of their equity as well as other marketable bank assets. Asset trading by informed investors can provide the supervisory board with valuable signals which alert supervisory board members to undesirable investment strategies. A declining stock price allows supervisory board members to challenge a CEO and/or request further explanations about the bank's investment policy. ${ }^{19}$ However, such external monitoring (due to public trading) may require a high degree of bank transparency beyond current accounting standards. This may explain why we find only a weak negative correlation between public trading of bank equity and bank losses in our sample. ${ }^{20}$

\footnotetext{
${ }^{16}$ Return to equity (if measured at market values) and per capita profits are both sensitive to financial leverage, which (according to book values) in Table 2, column (7) is higher for private banks. This could go some way in explaining higher relative profitability for these two measures.

${ }^{17}$ We also examined the variability of operating profits similar to Laeven and Levine (2008), but could not find any systematic difference between private and state-owned banks.

${ }^{18}$ Of course, per capita profits depend on the labour intensity of a business. However, as the state banks do not operate in the particularly labour-intensive market segment of consumer retail business, they should ceteris paribus have higher rather than lower per capita profits than their private counterparts.

19 Dahiya, Saunders and Srinivasan (2009) provide evidence that bank equity prices are informative of the solvency of bank lenders. See also Flannery and Sorescu (1996) and Berger, Davies, and Flannery (2000).

${ }^{20}$ We note that 6 of the 16 private banks and 2 of the 13 state-owned banks are publicly traded.
} 


\subsection{State Ownership as Managerial Constraint}

An alternative interpretation of the larger losses during the crisis is that state-owned banks face constraints not shared by their private sector competitors. Such a 'managerial constraint hypothesis' (H4) may apply particularly to salary limits for CEOs and top managers. The hypothesis could be relevant in a highly competitive managerial labour market, in which the most competent bank managers seek and obtain higher paid jobs in private banks. The poor financial performance of the state-owned banks in the current banking crisis could be a reflection of such 'suboptimal' managerial constraints. The low competence of the supervisory boards in this explanation would be accidental and irrelevant to the observed underperformance of state-owned banks.

The role of executive salaries is examined in Table 11. We use data on the executive board compensation of the 29 banks from the accounting statements in 2006. To avoid a possible bias due to different accounting standards (historic value vs. market value), we eliminate all (pension related) deferred compensation from the data. The total compensation of an executive board is then divided by the number of board members to obtain the average salary of an executive board member. We use the (log of the) average compensation as the dependent variable. The bank size measured by the log of total assets represents a highly significant control variable in all specifications. Larger banks pay higher salaries to their top level executives. This finding corresponds to very similar results for CEO salaries in the U.S. (Landier and Gabaix, 2008). The negative sign for the state bank dummy in column (1) reveals that executive board members earn on average less in state banks. But the average pay difference of $10 \%(=100 \times \exp (0.95)-100)$ is economically and statistically insignificant. It is rather implausible that such a small pay differential amounts to a managerial constraint in state banks to hire talented executive board members. Column (2) reveals that banks with a larger share of board members with political affiliations pay less to their executives. But a decrease of politically affiliated board representatives by one standard deviation (0.21) increases executive compensation by a modest $14 \%(=100 \times \exp (0.612 * 0.21)-100)$. We also note that the most competent supervisory boards did not approve considerably higher executive pay as is evident in column (3). An increase in financial board competence by one standard deviation increased executive pay only by $5 \%$. To the extent that the quality of the appointed executive boards drive operating and crisis performance, higher executive board quality appears to be available through better manager selection and/or board supervision rather than higher salaries.

We do not find any evidence for other managerial constraints which differentiate private and state-owned banks in Germany. Both private sector and state-owned banks operate in the same labour market for managerial talent; hence, it is hard to come up with any competitive disadvantage faced by the state-owned banks. The only difference is a historic public guarantee of state bank debt. The latter amounts to a competitive advantage not enjoyed by the private sector banks. The public guarantee ("Gewährträgerhaftung”) for the Landesbanken was revoked under EU competition law in 2001. This eliminated differences between public and private banks rather than being an additional constraint on public banks. There exists a generous interim arrangement, whereby the public guarantee is still valid for all liabilities which were incurred until 2005 and which become mature before 2015. It is occasionally argued that this interim arrangement could have created an incentive for cheap additional bank borrowing before July 2005. But accounting measures for leverage in Table 2, column (7), show in fact a lower leverage for state-owned banks than for private banks in 2006/7. For a lack of evidence, we discard hypothesis H4. 


\subsection{Executive Pay and Crisis Performance}

Even in the absence of significant pay difference between private and state banks, salary levels may still relate to managerial quality and therefore crisis performance. Does investment in a more expensive executive board pay off in times of crisis? According to the 'efficient executive pay hypothesis' (H5), higher executive salaries should be correlated with better crisis performance. But an inverse relationship between executive pay and crisis performance is also plausible. In this case higher salaries for the executive board members may just reflect a lack of effective supervisory board control and other agency problems. ${ }^{21}$

Table 12 revisits the crisis performance regressions with executive pay as an additional control variable. The bank losses positively correlate with the level of executive pay. This positive relationship is statistically significant at the 10 percent level once we also control for differences in financial supervisory board competence in column (3). Hence, the investment return to higher executive pay was ceteris paribus negative for German banks as better paid executives suffered larger losses - not smaller ones. This allows us to discredit the 'efficient executive pay' hypothesis. Underinvestment in executive pay packages is certainly not what explains the crisis performance of German banks.

\section{Summary with Policy Conclusions}

Economists have long recognized the fragility of bank institutions and the systemic risk that they pose to the real economy. Unlike most other limited liability companies, banks feature high leverage and their maturity transformation exposes them to additional liquidity risks more than any other industry sector. Their pivotal role in financing the investment activity of small and medium sized companies implies that financial distress by banks carries large macroeconomic costs. Banks should therefore be subject to a particular regulatory framework, which imposes minimum capital requirements, requires effective systems of internal risk management and appropriate disclosure policies.

The current financial crisis confirms these conventional views [IMF (2008)], but also provides some new lessons. The regulatory system did not sufficiently constrain the risk choices of many financial institutions. Particularly in the U.S., financial institutions such as investment banks were allowed to operate as a 'shadow banking system' outside of traditional banking supervision. The lenient regulation allowed the banks to reduce equity as far as possible in order to benefit from the higher returns which come with higher leverage. Moreover, political lobbying by the financial industry itself may have contributed to the lenient regulatory regime which rendered bank supervision less effective.

In the light of the recent experience, bank regulation needs to be strengthened. However, it is less clear how to shield national bank supervision from the very political interference which has weakened it in the past. More political independence of bank supervision similar to central bank independence seems desirable [Rochet (2008)]. Some have even called for an international financial regulator to provide political insulation from national politics [Reinhart and Rogoff (2008)]. Nevertheless, tougher banking regulation will have to face up to future political challenges which may again undermine its very effectiveness.

\footnotetext{
${ }^{21}$ High-powered incentives for the top management (e.g., through stock options) may influence managerial risktaking and therefore a bank's crisis performance. For instance, Mehran and Rosenberg (2007) show that CEO stock option holdings increase asset volatility. Unfortunately, there are no suitable data on performance pay for the 29 German banks under consideration.
} 
It is therefore important to explore parallel policy measures which may strengthen bank stability even further. Here, our performance and governance analysis of German banks in the recent financial crisis offers interesting insights. The large role played by state-owned banks in the German banking sector implies that corporate governance is extremely heterogeneous in an otherwise identical regulatory environment. Studying the biographies of 593 board members in the 29 largest German banks reveals that the financial and managerial competence of supervisory board members is systematically lower in state-owned banks compared to private banks. This statistically significant result should in itself raise concerns about the stateownership of bank unless one negates the monitoring role of supervisory boards altogether.

A performance comparison of state-owned and private banks in the 2007/2008 banking crisis reveals that state-owned banks performed significantly worse. Controlling for bank size, the losses of state-owned banks are on average three times as large as those of their private competitors. The small sample of 25 observations may raise robustness concerns. However, abundant anecdotal evidence on many previous large-scale investment failures by German state-owned banks is certainly not in contradiction to the statistical findings.

We then relate bank crisis performance directly to measures of supervisory board competence. The evidence suggests that the monitoring ability of the supervisory board matters for the financial fragility of banks. Financial expertise of the supervisory board correlates with crisis performance at a 5 percent statistical significance level even in our small sample. We interpret this correlation as a causal linkage from governance to crisis performance because the instrumented version of the same regression produces very similar regression coefficients. Assuming that CEOs of state-owned companies cannot alter the percentage of political representatives in their supervisory board, we can use this percentage as an exogenous instrument, which is nevertheless strongly correlated with financial board competence. Equal coefficients for the instrumented and ordinary regressions are evidence against the reverse causality, whereby particularly reckless bank CEOs co-opt incompetent board members as their monitors.

The analysis also undertakes some tentative steps in exploring the channel through which supervisory board competence could matter. For this, we distinguish between a strong and a weak monitoring hypothesis. The former assumes that supervisory board monitoring directly influences the quality of the key investment decisions by the executive board. The latter concedes that such a high level of supervisory board involvement may not be realistic. Instead, supervisory board competence matters through the selection of the executive board. Better executive selection improves operating performance and the latter avoids a 'gambling for profitability' which allegedly characterized the investment behaviour of state-owned banks. We check if state-owned banks indeed suffered from lower operating profitability and find supportive evidence. Moreover, higher financial board competence also correlates with better operating performance. Risky investment choices might therefore have been the flipside to poor operating performance.

Finally, we explore the role of executive pay for the crisis performance. There is no evidence for the 'efficient executive pay hypothesis' whereby the return to higher executives compensation consists in better investment strategies and less bank fragility. We rather find evidence to the contrary. Higher executive pay correlates with higher crisis losses, which suggest that particularly large executive pay package signal not better management but rather more severe agency problems.

Overall, our case study shows that state ownership comes at the costs of weaker monitoring of bank managers, possibly higher risk exposure and higher bank losses in a financial crisis. This finding is important given that state-ownership has even increased in the wake of the current crisis. The policy conclusions are straightforward. First, state ownership in the banking sector 
should be reduced as far as possible. ${ }^{22}$ Second, whenever state ownership is unavoidable, the financial competences of the supervisory boards have to be strengthened. Instead of installing politically connected board members, the state should delegate financial experts to the supervisory boards. Third, private institutions may similarly benefit from a more competent supervisory board. ${ }^{23}$ Enhanced shareholder rights and better shareholder representation can also pave the way for more bank board quality and more effective monitoring. Fourth, the quality of bank monitoring may increase if supervisory board members dispose of market signals indicative of bank risk. This calls for stock market quotation of bank equity as well as exchange trading of marketable bank assets. We note that more information from market prices under enhanced bank transparency can also improve regulatory supervision. Fifth, it seems worth exploring whether prudential bank regulations should explicitly encompass criteria for board competence and quality. These measures offer a promising path towards more financial stability because at the heart of any financial crisis are large bank losses.

\section{References}

Baysinger, B. and H. Butler (1985). 'Corporate Governance and Board of Directors: Performance Effects of Changes in Board Composition', Journal of Law, Economics and Organization 1, 101-124.

Becker, B., H. Cronqvist, and R. Fahlenbrach (2008). Estimating the Effect of Large Shareholders Using a Geographic Instrument, Working Paper, Ohio State University.

Berger, A., S. Davies and M.J. Flannery (2000). 'Comparing Market and Regulatory Assessments of Bank Performance: Who Knows What When?' Journal of Money, Credit and Banking 32, 641-667.

Bertrand, M., F. Kramarz, A. Schoar and D. Thesmar (2008). Political Connections and Corporate Performance: An analysis on French CEOs, Working paper, HEC Paris.

Bhagat, S., and B. Black (2002). 'The Non-correlation between Board Independence and Long-term Performance', Journal of Corporation Law 27, 231-273.

Brown, W. O. and M. T. Maloney (1999). Exit, Voice, and the Role of Corporate Directors: Evidence from Acquisition Performance, Unpublished manuscript, Claremont McKenna College.

Brunner, A., J. Decressin, D. Hardy and B. Kudela (2004). Germany's Three-Pillar Banking System: Cross-Country Perspectives in Europe, IMF Occasional Paper No. 233, Washington, DC.

ECB (2008). EU Banking Structures 2008, October 2008, Frankfurt.

Dahiya, S., A. Saunders and A. Srinivasan (2009). 'Financial Distress and Bank Lending Relationships', Journal of Finance, forthcoming.

Flannery, M. and S. Sorescu (1996). 'Evidence of Bank Market Discipline in Subordinated Debenture Yields: 1983-1991’, Journal of Finance 51, 1347-1377.

\footnotetext{
${ }^{22}$ Note that the German public banks, which are under consideration in this study, simply compete with private banks and hardly fulfill any public service function. There may be some limited role for public development banks which hand out subsidized loans to municipalities and public institutions. Such development banks, however, are beyond the scope of our study.

${ }^{23}$ Governance failure can also be severe in private companies as the spectacular collapse of Enron and Worldcom shows. The Sarbanes-Oxley act of 2002 was passed as a consequence. Its scope is limited to the U.S. and it focuses on formal aspects of governance rather than its qualitative dimensions.
} 
Güner, A B., U. Malmendier and G. Tate (2008). 'Financial Expertise of Directors', Journal of Financial Economics 88, 323-354.

Hellwig, M. (2008). 'The Causes of the Financial Crisis', CESifo Forum, Vol. 9(4), 12-21.

Hermalin, B. and M. Weisbach (1991). 'The Effects of Board Composition and Direct Incentives on Firm Performance', Financial Management 20, 101-112.

IMF (2006). Germany: Selected Issues, IMF Country Report No. 06/436, December 2006, Washington, DC.

IMF (2008). Global Financial Stability Report - Containing Systemic Risks and Restoring Financial Soundness, April 2008, Washington, DC.

Klein, A. (1995). 'Firm Performance and Board Committee Structure', Journal of Law and Economics 41, 275-303.

Krahnen, J. P. and R. H. Schmidt (2004). The German Financial System, Oxford University Press, Oxford.

Kramarz, F. and D. Thesmar (2008). Beyond Independence: Social Networks in the Boardroom, Working Paper, HEC Paris.

La Porta, R., F. Lopez-de-Silanes, and A. Shleifer (2002). 'Government Ownership of Banks', Journal of Finance 57, 256-301.

Laeven, L., and R. Levine (2008). 'Bank Governance, Regulation, and Risk Taking', NBER working paper 14113, National Bureau of Economic Research, Inc.

Landier, A. and X. Gabaix (2008). 'Why Has CEO Pay Increased So Much?', Quarterly Journal of Economics 123, 49-100.

MacAvoy, P. W., S. Cantor, J. Dana and S. Peck (1983). ALI Proposals for Increased Control of the Corporation by the Board of Directors: An Economic Analysis, In: Statement of the Business Roundtable on the American Law Institute's proposed 'Principles of Corporate Governance and Structure: Restatement and Recommendations'.

Mehran, H. (1995). 'Executive Compensation Structure, Ownership, and Firm Performance' Journal of Financial Economics 38, 163-84.

Mehran, H. and J.V. Rosenberg (2007). The Effect of Employee Stock Options on Bank Investment Choice, Borrowing, and Capital, FRB of New York Staff Report No. 305.

Morck, R., A. Shleifer and R. Vishny (1988). 'Management Ownership and Market Valuation: An Empirical Analysis’, Journal of Financial Economics 20, 293-316.

Münchau, W. (2008). 'Another Landesbank bites the dust', available at the Eurointelligence website: http://www.eurointelligence.com/Article3.1018+M50fcec22186.0.html.

Papakonstantinou, F. (2008). Boards of Directors: The Value of Industry Experience, mimeo, Princeton University.

Reinhart, C. and K. Rogoff (2008). 'Regulation should be international', Financial Times, November 18, 2008.

Rochet, J-Ch. (2008). Why Are There So Many Banking Crises? The Politics and Policy of Bank Regulation, Princeton University Press, Princeton, NJ.

Sapienza, P. (2004). 'The Effects of Government Ownership on Bank Lending', Journal of Financial Economics 72, 357-384. 
Schellinger, M., D. Wood and A. Tashakori (1989). 'Board of Director Composition, Shareholder Wealth, and Dividend Policy’, Journal of Management 15, 457-467.

Sachverständigenrat (2008). Das deutsche Finanzsystem. Effizienz steigern - Stabilität erhöhen, Report of the Council of Economic Advisors to the German Federal Government, Wiesbaden, June 2008.

Sinn, H.-W. (1999). The German State Banks. Global Players in the International Financial Markets, Edward Elgar, Cheltenham.

Tett, G. (2008). 'Insight: Anthropological Insights into Banking Behaviour', Financial Times, January 17, 2008.

Vins, O. (2008). How Politics Influence State-owned Banks - The Case of German Savings Banks, Working Paper No. 191, Johann Wolfgang Goethe University.Frankfurt.

Yermack, D. (1996). 'Higher market valuation of companies with a small board of directors', Journal of Financial Economics 40, 185-211. 
Table 1: Capital Injections to State-Owned Banks (Landesbanken) from 1991 to 2005

State-Owned Bank

\section{Capital Injections (in $€$ millions)}

Bayern LB

Hamburgische LB

Helaba

406

HSH Nordbank

400

LB Berlin

2,560

LB Kiel

432

Norddeutsche LB

472

West LB

3,729

Total

8,749

Source: IMF $(2006,91)$ 
Table 2: Financial Statistics for the 29 Banks in the Sample

\begin{tabular}{|c|c|c|c|c|c|c|c|c|c|}
\hline Bank & $\begin{array}{c}\text { Acc. } \\
\text { Stan- } \\
\text { dards }^{a}\end{array}$ & $\begin{array}{c}\text { Dummy } \\
\text { (State } \\
\text { Owned = } \\
\text { 1) }^{b}\end{array}$ & $\begin{array}{c}\text { Total } \\
\text { Assets } \\
\text { (b. €, } \\
\text { 2006/07) } \\
\\
(3)\end{array}$ & $\begin{array}{c}\text { Equity } \\
\text { Capital } \\
\text { (b. } € \text { 2006/07) } \\
\text { (4) }\end{array}$ & $\begin{array}{c}\text { Tier } 1 \\
\text { Capital } \\
\text { (b. } € \\
\text { 2007/08) } \\
\\
(5)\end{array}$ & $\begin{array}{c}\text { Total } \\
\text { Losses } \\
\text { (b. €) }\end{array}$ & $\begin{array}{c}\text { Leverage } \\
\begin{array}{c}(7) \\
=(3) /(4)\end{array}\end{array}$ & $\begin{array}{c}\text { Losses / } \\
\text { Total } \\
\text { Assets (\%) } \\
\\
(8) \\
=(5) \\
* 100 /(4) \\
\end{array}$ & $\begin{array}{c}\text { Losses / } \\
\text { Equity } \\
\text { Capital } \\
(\%) \\
(9) \\
=(5) \\
* 100 /(3) \\
\end{array}$ \\
\hline Deutsche Bank & $\mathrm{hv} / \mathrm{mv}$ & 0 & 2005.5 & 36.07 & 25.9 & 8.45 & 55.6 & 0.42 & 23.43 \\
\hline Commerzbank & $\mathrm{mv}$ & 0 & 615.8 & 15.77 & 6.90 & 2.95 & 39.1 & 0.48 & 18.70 \\
\hline Dresdner Bank & $\mathrm{mv}$ & 0 & 489.4 & 11.36 & 11.85 & 3.40 & 43.1 & 0.69 & 29.93 \\
\hline LBBW & $\mathrm{hv} / \mathrm{mv}$ & 1 & 471.9 & 21.35 & 11.55 & 3.27 & 22.1 & 0.68 & 15.07 \\
\hline HVB Group & $\mathrm{mv}$ & 0 & 435.7 & 23.90 & 11.55 & 1.16 & 18.2 & 0.27 & 4.87 \\
\hline DZ Bank & $\mathrm{hv} / \mathrm{mv}$ & 0 (со) & 430.6 & 10.55 & 9.35 & 2.30 & 40.8 & 0.53 & 21.77 \\
\hline Bayern LB & $\mathrm{hv} / \mathrm{mv}$ & 1 & 415.6 & 12.22 & 6.40 & 5.81 & 34.0 & 1.16 & 39.40 \\
\hline Hypo Real Estate ${ }^{\text {d }}$ & $\mathrm{mv}$ & 0 & 397.8 & 7.95 & 5.90 & 1.41 & 50.0 & 0.35 & 17.74 \\
\hline KfW Group & $\mathrm{hv} / \mathrm{mv}$ & 1 & 361.0 & 14.94 & 9.64 & 3.77 & 24.2 & 0.94 & 22.76 \\
\hline WestLB & $\mathrm{hv} / \mathrm{mv}$ & 1 & 277.2 & 4.80 & 6.50 & 4.04 & 57.8 & 1.15 & 66.13 \\
\hline Nord LB & $\mathrm{hv} / \mathrm{mv}$ & 1 & 220.2 & 6.13 & 6.60 & 0.92 & 35.9 & 0.42 & 15.07 \\
\hline Postbank & $\mathrm{mv}$ & 0 & 215.8 & 4.79 & 5.10 & 1.15 & 45.1 & 0.53 & 23.97 \\
\hline Eurohypo & $\mathrm{hv} / \mathrm{mv}$ & 0 & 207.1 & 5.28 & 5.15 & 0.39 & 39.2 & 0.19 & 7.40 \\
\hline HSH Nordbank & $\mathrm{mv}$ & 1 & 204.6 & 4.44 & 7.55 & 2.60 & 46.0 & 1.13 & 52.00 \\
\hline Helaba & $\mathrm{hv} / \mathrm{mv}$ & 1 & 174.2 & 4.86 & 4.90 & 0.69 & 35.9 & 0.3 & 10.79 \\
\hline NRW Bank & hv & 1 & 145.4 & 19.58 & 3.10 & --- & 7.4 & --- & -- \\
\hline Landesbank Berlin & $\mathrm{hv} / \mathrm{mv}$ & 1 & 144.4 & 2.55 & 3.85 & 1.41 & 56.7 & 0.72 & 41.05 \\
\hline Dekabank & $\mathrm{hv} / \mathrm{mv}$ & 1 & 121.8 & 3.32 & 2.10 & 0.58 & 36.6 & 0.40 & 14.47 \\
\hline WGZ Bank AG & $\mathrm{hv} / \mathrm{mv}$ & 0 (со) & 90.0 & 2.83 & 2.20 & 0.25 & 31.8 & 0.28 & 8.86 \\
\hline Essenhyp & hv & 0 & 89.9 & 0.72 & 0.80 & --- & 124.6 & --- & -- \\
\hline DG-Hypothekenbank & hv & 0 (со) & 80.5 & 1.92 & 1.40 & 0.16 & 41.9 & 0.20 & 8.44 \\
\hline LRP Landesbank Rheinland-Pfalz & $\mathrm{hv} / \mathrm{mv}$ & 1 & 77.9 & 0.99 & 2.10 & 0.30 & 79.0 & 0.38 & 30.40 \\
\hline Sachsen LB & hv & 1 & 62.1 & 1.42 & 1.30 & 1.80 & 43.8 & 2.90 & 127.03 \\
\hline Depfa Deutsche Pfandbrief Bank AG & hv & 0 & 53.6 & 0.82 & 0.84 & --- & 65.2 & --- & -- \\
\hline IKB & $\mathrm{hv} / \mathrm{mv}$ & $1^{\mathrm{c}}$ & 50.2 & 1.18 & 2.15 & 5.13 & 42.4 & 10.22 & 433.53 \\
\hline Dexia Deutschland AG & hv & 0 & 48.3 & 0.29 & 0.28 & 0.02 & 164.7 & 0.04 & 5.8 \\
\hline Berlin-Hannoversche Hypothekenbank AG & hv & 0 & 42.5 & 0.72 & 0.64 & 0.06 & 58.8 & 0.14 & 8.04 \\
\hline WL Bank AG & hv & 0 (со) & 41.0 & 0.32 & 0.51 & --- & 126.5 & --- & --- \\
\hline Sal. Oppenheim jr. \& Cie. KGaA & $\mathrm{hv} / \mathrm{mv}$ & 0 & 40.1 & 2.00 & 1.80 & 0.57 & 20.0 & 1.41 & 28.19 \\
\hline Average Overall & & & 276.2 & 7.69 & 5.44 & 2.10 & 51.3 & 1.04 & 42.99 \\
\hline Av. Private Banks & & & 330.2 & 7.83 & 5.64 & 1.71 & 60.3 & 0.43 & 15.9 \\
\hline Av. State-Owned B. & & & 209.7 & 7.52 & 5.20 & 2.52 & 40.1 & 1.70 & 72.3 \\
\hline Spearman Rank Test & & & 0.865 & 0.493 & 0.453 & 0.117 & 0.209 & 0.009 & 0.009 \\
\hline
\end{tabular}

Notes: ${ }^{a}$ We distinguish historical value accounting (hv) and market value accounting (mv). Historical value accounting follows the German GAAP (HGB). Market value based accounting standards include US-GAAP, IFRS, IAS. Several banks have changed their accounting standards in the period under consideration (hv/mv). ${ }^{\mathrm{b}}$ Cooperative banks are labelled "(co)" in column (2). ${ }^{\mathrm{C}}$ In January 2008, IKB was formally a private bank but the state-owned bank KfW was the largest shareholder. ${ }^{\mathrm{d}}$ Additional goodwill losses of the HRE in 2008 were related to the M\&A activities (Depfa) and were excluded from the data set as we focus on operating profits and losses. 


\section{Table 3: Summary Statistics}

Reported are summary statistics for (the log of) total assets, leverage (as the ratio of total assets to book equity) and tier 1 capital averaged in each case over 2006 and 2007. Losses include the operating profits for the 7 quarters from 2007/1 to 2008/3 and all public announcements of losses until the end of 2008. Biographical information on 593 supervisory board members is aggregated into 4 measures of supervisory board competence, namely the educational index (AIE), the average management experience (AIM), the average finance experience (AIF) and the aggregate total experience measure (AIT). Operating performance measures for the period 1998-2006 are taken from Bankscope. Per capita profits refer to operating profits per employee in each year. Executive pay represents the average annual salary in 2006 of the executive board members.

\begin{tabular}{|c|c|c|c|c|c|c|}
\hline & $\begin{array}{l}\text { Obs. } \\
(1)\end{array}$ & $\begin{array}{c}\text { Mean } \\
(2) \\
\end{array}$ & $\begin{array}{l}\text { Min } \\
(3)\end{array}$ & $\begin{array}{l}\text { Max } \\
(4) \\
\end{array}$ & $\begin{array}{l}\text { Median } \\
\text { (5) }\end{array}$ & $\begin{array}{c}\text { Std. Dev. } \\
(6)\end{array}$ \\
\hline \multicolumn{7}{|l|}{ Bank Variables: } \\
\hline Dummy (State-Owned = 1) & 29 & 0.448 & 0 & 0 & 1 & 0.506 \\
\hline Log of Total Assets & 29 & 5.101 & 3.691 & 7.604 & 5.160 & 0.996 \\
\hline Log of Leverage & 29 & 3.760 & 2.005 & 5.104 & 3.748 & 0.611 \\
\hline Log of Tier 1 Capital & 29 & 1.552 & 0.247 & 3.292 & 1.677 & 0.767 \\
\hline Log of Loss/Assets & 25 & 0.011 & 0.000 & 0.097 & 0.005 & 0.019 \\
\hline Log of Loss & 25 & 0.933 & 0.017 & 2.246 & 0.878 & 0.634 \\
\hline \multicolumn{7}{|l|}{ Board Variables: } \\
\hline AIE & 29 & 0.223 & 0 & 0.593 & 0.201 & 0.158 \\
\hline AIM & 29 & 0.562 & 0.095 & 1.386 & 0.511 & 0.322 \\
\hline AIF & 29 & 0.511 & 0 & 1.504 & 0.405 & 0.428 \\
\hline AIT & 29 & 0.953 & 0.182 & 2.058 & 0.871 & 0.506 \\
\hline Political Affiliations & 29 & 0.182 & 0 & 0.722 & 0.125 & 0.209 \\
\hline \multicolumn{7}{|c|}{ Operating Performance Measures: } \\
\hline Return on Book Assets & 266 & 0.002 & -0.017 & 0.021 & 0.002 & 0.004 \\
\hline Return on Book Equity & 266 & 0.069 & -2.715 & 0.737 & 0.096 & 0.219 \\
\hline Per Capita Profits & 266 & 0.131 & -1.993 & 4.637 & 0.078 & 0.429 \\
\hline \multicolumn{7}{|l|}{ Executive Board Variable: } \\
\hline Log of Excecutive Pay & 26 & 0.735 & 0.231 & 2.121 & 0.620 & 0.383 \\
\hline
\end{tabular}

Source: Authors’ calculation 


\section{Table 4: Bank Losses of Private and State-Owned Banks in the Financial Crisis}

Reported are OLS regressions for the (log of the) bank losses in the period 2007-2008 for 25 German banks. Specification (1) uses the bank losses normalized by total assets as the dependent variable, while specifications (2) to (5) use absolute bank losses (in logs) as the dependent variable. The regressions controls are bank size measured by the log of total assets, $\log$ of tier 1 capital and leverage defined as the log ratio of total assets over bank equity capital at book value. The t-values of the coefficients are reported in brackets. We mark statistical significance at the 10 percent level $(*)$, the 5 percent level $(* *)$ and 3 percent level $(* * *)$.

\begin{tabular}{|c|c|c|c|c|c|}
\hline \multirow[b]{2}{*}{ Independent Variables } & \multicolumn{5}{|c|}{ Dependent Variables } \\
\hline & $\begin{array}{c}\log (\text { Loss/ } \\
\text { Total Assets) } \\
(1) \\
\end{array}$ & $\begin{array}{c}\log (\text { Loss }) \\
(2)\end{array}$ & $\begin{array}{c}\log (\text { Loss }) \\
(3)\end{array}$ & $\begin{array}{c}\log (\text { Loss }) \\
(4) \\
\end{array}$ & $\begin{array}{c}\log (\text { Loss }) \\
(5)\end{array}$ \\
\hline Constant & $\begin{array}{r}-5.768 * * * \\
{[-22.34]}\end{array}$ & $\begin{array}{r}-6.176 * * * \\
{[-5.74]}\end{array}$ & $\begin{array}{c}-2.612 \\
{[-1.25]}\end{array}$ & $\begin{array}{r}-1.988 * * * \\
{[-6.57]}\end{array}$ & $\begin{array}{l}-1.504 \\
{[-0.88]}\end{array}$ \\
\hline Dummy (State-Owned =1) & $\begin{array}{r}1.194^{* * *} \\
{[3.20]}\end{array}$ & $\begin{array}{r}1.208^{* * *} \\
\text { [3.17] }\end{array}$ & $\begin{array}{r}1.146^{* * * *} \\
{[3.18]}\end{array}$ & $\begin{array}{r}0.845^{* * * *} \\
{[2.68]}\end{array}$ & $\begin{array}{r}0.842^{* * * *} \\
{[2.61]}\end{array}$ \\
\hline Log of Total Assets & & $\begin{array}{r}1.077 * * * \\
{[5.36]}\end{array}$ & $\begin{array}{r}0.983^{* * *} \\
{[5.16]}\end{array}$ & & \\
\hline Log of Leverage & & & $\begin{array}{r}-0.817^{*} \\
{[-1.95]}\end{array}$ & & $\begin{array}{l}-0.120 \\
{[-0.29]}\end{array}$ \\
\hline Log of Tier 1 Capital & & & & $\begin{array}{r}1.157^{* * * *} \\
{[7.36]}\end{array}$ & $\begin{array}{r}1.132 * * * \\
{[6.17]}\end{array}$ \\
\hline Obs. & 25 & 25 & 25 & 25 & 25 \\
\hline Adj. $R^{2}$ & 0.279 & 0.596 & 0.641 & 0.723 & 0.711 \\
\hline
\end{tabular}

Source: Authors’ calculation 


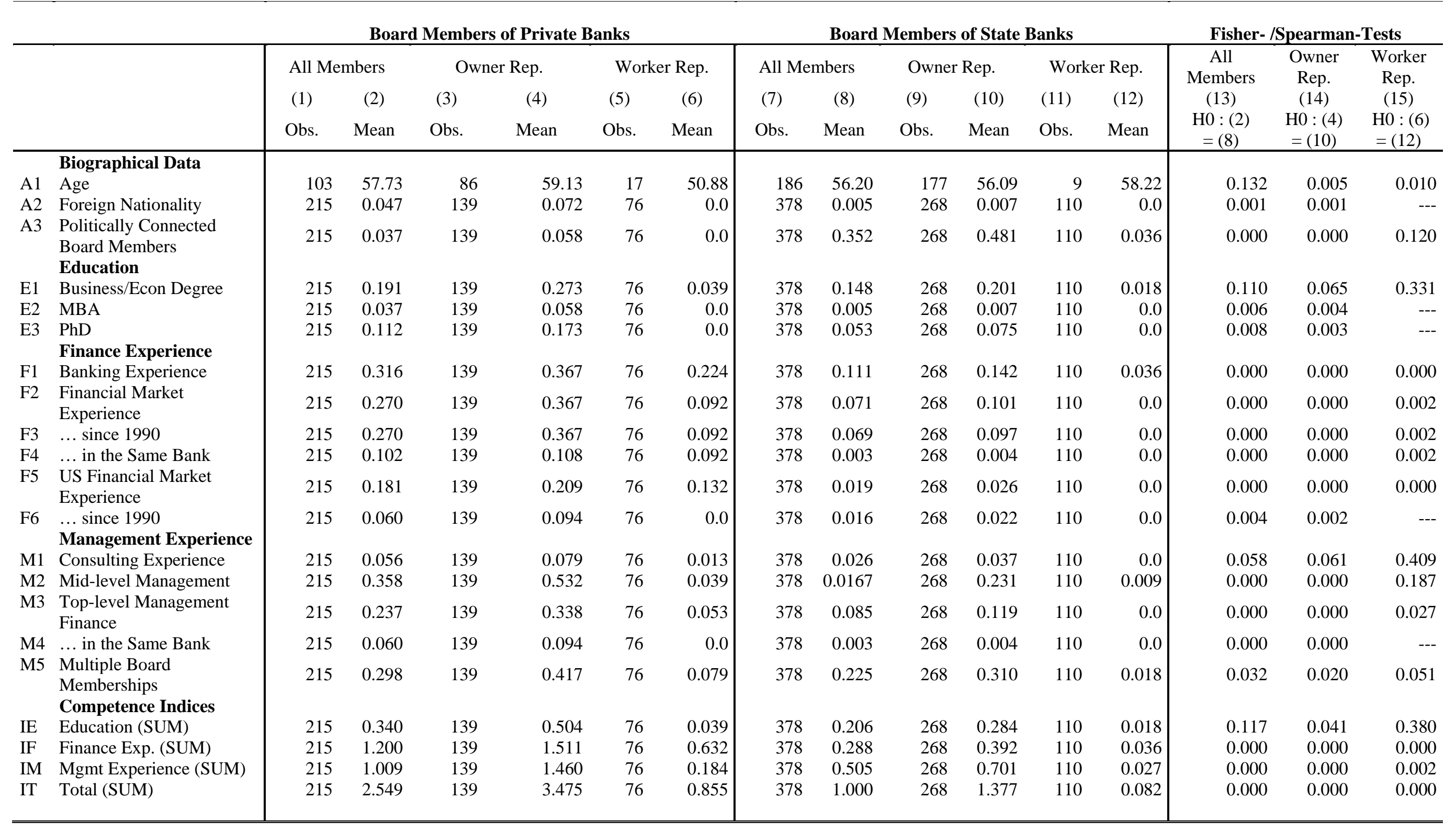


Board Members of Private and State Banks

\begin{tabular}{|c|c|c|c|c|c|c|c|c|}
\hline & & \multicolumn{2}{|c|}{ All Members } & \multicolumn{2}{|c|}{$\begin{array}{l}\text { Politically } \\
\text { Connected } \\
\text { Members. }\end{array}$} & \multicolumn{2}{|c|}{ Other Members } & \multirow{3}{*}{$\begin{array}{c}\text { Fisher- } \\
\text { /Spearman- } \\
\text { Test } \\
(7) \\
\text { HO : }(4)=(6)\end{array}$} \\
\hline & & $(1)$ & $(2)$ & $(3)$ & $(4)$ & $(5)$ & $(6)$ & \\
\hline & & Obs. & Mean & Obs. & Mean & Obs. & Mean & \\
\hline & \multicolumn{8}{|l|}{ Biographical Data } \\
\hline A1 & Age & 263 & 57.07 & 136 & 56.04 & 127 & 58.18 & 0.072 \\
\hline \multirow[t]{2}{*}{$\mathrm{A} 2$} & Foreign Nationality & 407 & 0.029 & 137 & 0.000 & 270 & 0.044 & 0.007 \\
\hline & Education & & & & & & & \\
\hline E1 & Business/Econ Degree & 407 & 0.226 & 137 & 0.241 & 270 & 0.219 & 0.348 \\
\hline E2 & MBA & 407 & 0.025 & 137 & 0.022 & 270 & 0.026 & 0.550 \\
\hline \multirow[t]{2}{*}{ E3 } & $\mathrm{PhD}$ & 407 & 0.101 & 137 & 0.066 & 270 & 0.119 & 0.064 \\
\hline & Finance Experience & & & & & & & \\
\hline $\mathrm{F} 1$ & Banking Experience & 407 & 0.219 & 137 & 0.088 & 270 & 0.285 & 0.000 \\
\hline F2 & Financial Market Experience & 407 & 0.192 & 137 & 0.029 & 270 & 0.274 & 0.000 \\
\hline F3 & $\ldots$ since 1990 & 407 & 0.189 & 137 & 0.029 & 270 & 0.270 & 0.000 \\
\hline F4 & $\ldots$ in the Same Bank & 407 & 0.039 & 137 & 0.007 & 270 & 0.056 & 0.012 \\
\hline F5 & US Financial Market Experience & 407 & 0.081 & 137 & 0.000 & 270 & 0.122 & 0.000 \\
\hline \multirow[t]{2}{*}{ F6 } & $\ldots$ since 1990 & 407 & 0.047 & 137 & 0.000 & 270 & 0.070 & 0.000 \\
\hline & Management Experience & & & & & & & \\
\hline M1 & Consulting Experience & 407 & 0.052 & 137 & 0.066 & 270 & 0.044 & 0.245 \\
\hline M2 & Mid-level Management & 407 & 0.334 & 137 & 0.190 & 270 & 0.407 & 0.000 \\
\hline M3 & Toplevel Management Finance & 407 & 0.194 & 137 & 0.088 & 270 & 0.248 & 0.000 \\
\hline M4 & $\ldots$ in the Same Bank & 407 & 0.034 & 137 & 0.007 & 270 & 0.048 & 0.024 \\
\hline \multirow[t]{2}{*}{ M5 } & Multiple Board Memberships & 407 & 0.346 & 137 & 0.380 & 270 & 0.330 & 0.186 \\
\hline & Competence Indices & & & & & & & \\
\hline IE & Education (SUM) & 407 & 0.351 & 137 & 0.328 & 270 & 0.363 & 0.884 \\
\hline IF & Finance Experience (SUM) & 407 & 0.767 & 137 & 0.153 & 270 & 1.078 & 0.000 \\
\hline $\mathrm{IM}$ & Mgmt Experience (SUM) & 407 & 0.961 & 137 & 0.730 & 270 & 1.078 & 0.174 \\
\hline IT & Total (SUM) & 407 & 2.079 & 137 & 1.212 & 270 & 2.519 & 0.109 \\
\hline
\end{tabular}

Source: Authors' calculation 


\section{Table 7: Relative Bank Losses and Supervisory Board Competence}

Reported are OLS regressions for the (log of the) bank losses in the period 2007-2008 relative to total assets (at the end of 2007) for 25 German banks. As the independent variable we use 4 measures of supervisory board competence, namely the educational index (AIE), the average management experience (AIM), the average finance experience (AIF) and the aggregate total experience measure (AIT). The t-values of the coefficients are reported in brackets. We mark statistical significance at the 10 percent level $(*)$, the 5 percent level $\left({ }^{* *}\right)$ and the 3 percent level (***).

\begin{tabular}{|c|c|c|c|c|}
\hline \multirow[b]{2}{*}{ Independent Variables } & \multicolumn{4}{|c|}{ Dependent Variable: $\log ($ Loss/Total Assets) } \\
\hline & $(1)$ & $(2)$ & $(3)$ & $(4)$ \\
\hline Constant & $\begin{array}{r}-5.479 * * * \\
{[-13.89]}\end{array}$ & $\begin{array}{r}-4.866^{* * *} \\
{[-10.84]}\end{array}$ & $\begin{array}{r}-4.677 * * * \\
{[-15.33]}\end{array}$ & $\begin{array}{r}-4.66 * * * \\
{[-10.35]}\end{array}$ \\
\hline Education (AIE) & $\begin{array}{r}1.294 \\
{[0.87]}\end{array}$ & & & \\
\hline Mgmt. Experience (AIM) & & $\begin{array}{l}-0.588 \\
{[-0.84]}\end{array}$ & & \\
\hline Finance Experience (AIF) & & & $\begin{array}{r}-1.083 * * \\
{[-2.27]}\end{array}$ & \\
\hline Total Experience (AIT) & & & & $\begin{array}{c}-0.577 \\
{[-1.35]}\end{array}$ \\
\hline $\begin{array}{l}\text { Obs. } \\
\text { Adj. R-squared }\end{array}$ & $\begin{array}{r}25 \\
0.000\end{array}$ & $\begin{array}{r}25 \\
0.000\end{array}$ & $\begin{array}{r}25 \\
0.147\end{array}$ & $\begin{array}{r}25 \\
0.033\end{array}$ \\
\hline
\end{tabular}

Source: Authors’ calculation 


\section{Table 8: Absolute Bank Losses with Size Controls}

Reported are OLS regressions for the (log of the) bank losses in the period 2007-2008 for 25 German banks. As the independent variable we use 4 measures of supervisory board competence, namely the educational index (AIE), the average management experience (AIM), the average finance experience (AIF) and the aggregate total experience measure (AIT). Each regression controls for the bank size by using either (the log of) the total bank assets or (the log of) tier 1 capital. The t-values of the coefficients are reported in brackets. We mark statistical significance at the 10 percent level (*), the 5 percent level $(* *)$ and the 3 percent level $(* * *)$.

\begin{tabular}{|c|c|c|c|c|c|c|c|c|}
\hline \multirow[b]{2}{*}{ Independent Variables } & \multicolumn{8}{|c|}{ Dependent Variable: log(Loss) } \\
\hline & (1) & (2) & (3) & $(4)$ & $(5)$ & (6) & (7) & (8) \\
\hline Constant & $\begin{array}{r}-5.193 * * * \\
{[-4.20]}\end{array}$ & $\begin{array}{r}-5.296 * * * \\
{[-4.37]}\end{array}$ & $\begin{array}{r}-5.606 * * * \\
{[-5.00]}\end{array}$ & $\begin{array}{r}-5.262 * * * \\
{[-4.39]}\end{array}$ & $\begin{array}{r}-1.687 * * * \\
{[-4.70]}\end{array}$ & $\begin{array}{r}-1.351 * * * \\
{[-3.40]}\end{array}$ & $\begin{array}{r}-1.301 * * * \\
{[-4.09]}\end{array}$ & $\begin{array}{r}-1.220 * * * \\
{[-3.06]}\end{array}$ \\
\hline Education (AIE) & $\begin{array}{r}1.439 \\
{[0.88]}\end{array}$ & & & & $\begin{array}{r}0.462 \\
{[0.35]}\end{array}$ & & & \\
\hline Mgmt. Experience (AIM) & & $\begin{array}{c}-0.682 \\
{[-0.90]}\end{array}$ & & & & $\begin{array}{l}-0.621 \\
{[-1.07]}\end{array}$ & & \\
\hline Finance Experience (AIF) & & & $\begin{array}{r}-1.224 * * * \\
{[-2.41]}\end{array}$ & & & & $\begin{array}{r}-0.867 * * \\
{[-2.21]}\end{array}$ & \\
\hline Total Experience (AIT) & & & & $\begin{array}{r}-0.658 \\
{[-1.43]}\end{array}$ & & & & $\begin{array}{l}-0.532 \\
{[-1.52]}\end{array}$ \\
\hline Log of Total Assets & $\begin{array}{r}0.924 * * * \\
{[3.81]}\end{array}$ & $\begin{array}{r}1.072 * * * \\
{[4.44]}\end{array}$ & $\begin{array}{r}1.190 * * * \\
{[5.39]}\end{array}$ & $\begin{array}{r}1.136 * * * \\
{[4.71]}\end{array}$ & & & & \\
\hline Log of Tier 1 Capital & & & & & $\begin{array}{r}1.136^{* * * *} \\
{[5.86]}\end{array}$ & $\begin{array}{r}1.240 * * * \\
{[6.79]}\end{array}$ & $\begin{array}{r}1.252 * * * \\
{[7.55]}\end{array}$ & $\begin{array}{r}1.160 * * * \\
{[5.87]}\end{array}$ \\
\hline Obs. & 25 & 25 & 25 & 25 & 25 & 25 & 25 & 25 \\
\hline Adj. R-squared & 0.432 & 0.433 & 0.535 & 0.462 & 0.634 & 0.651 & 0.699 & 0.667 \\
\hline
\end{tabular}

Source: Authors’ calculation 


\section{Table 9: IV Regressions for Absolute Bank Losses with Size Controls}

Reported are instrumental variable (IV) regressions for the (log of the) bank losses in the period 2007-2008 for 25 German banks. As the independent variable we use 4 measures of supervisory board competence, namely the educational index (AIE), the average management experience (AIM), the average finance experience (AIF) and the aggregate total experience measure (AIT). As instruments for board competence we use a dummy variable for state-owned banks and the percentage of politically appointed board members. Each regression controls for the bank size by using either (the log of) the total bank assets or (the log of) tier 1 capital. The t-values of the coefficients are reported in brackets. We mark statistical significance at the 10 percent level $(*)$, the 5 percent level $(* *)$ and the 3 percent level $(* * *)$.

\begin{tabular}{|c|c|c|c|c|c|c|c|c|}
\hline \multirow[b]{2}{*}{ Independent Variables } & \multicolumn{8}{|c|}{ Dependent Variable: $\log ($ Loss $)$} \\
\hline & $(1)$ & $(2)$ & (3) & $(4)$ & $(5)$ & (6) & (7) & (8) \\
\hline Constant & $\begin{array}{r}-6.232 * * \\
{[-2.14]}\end{array}$ & $\begin{array}{r}-5.306 * * * \\
{[-3.31]}\end{array}$ & $\begin{array}{r}-5.910 * * * \\
{[-4.63]}\end{array}$ & $\begin{array}{r}-5.191 * * * \\
{[-3.54]}\end{array}$ & $\begin{array}{r}-0.077 \\
{[-0.05]}\end{array}$ & $\begin{array}{l}-0.325 \\
{[-0.39]}\end{array}$ & $\begin{array}{r}-0.924 * * \\
{[-2.05]}\end{array}$ & $\begin{array}{l}-0.320 \\
{[-0.42]}\end{array}$ \\
\hline Education (AIE) & $\begin{array}{r}-13.485 \\
{[-0.85]}\end{array}$ & & & & $\begin{array}{r}-11.510 \\
{[-1.06]}\end{array}$ & & & \\
\hline Mgmt. Experience (AIM) & & $\begin{array}{l}-3.649 \\
{[-1.62]}\end{array}$ & & & & $\begin{array}{l}-2.950 \\
{[-1.75]}\end{array}$ & & \\
\hline Finance Experience (AIF) & & & $\begin{array}{r}-2.415 * * \\
{[-2.23]}\end{array}$ & & & & $\begin{array}{r}-1.879 * * \\
{[-2.22]}\end{array}$ & \\
\hline Total Experience (AIT) & & & & $\begin{array}{r}-2.177 * \\
{[-1.84]}\end{array}$ & & & & $\begin{array}{r}-1.717 * \\
{[-1.94]}\end{array}$ \\
\hline Log of Total Assets & $\begin{array}{c}1.763 * \\
{[1.74]}\end{array}$ & $\begin{array}{r}1.410 * * * \\
{[3.65]}\end{array}$ & $\begin{array}{r}1.357 * * * \\
{[4.87]}\end{array}$ & $\begin{array}{r}1.383^{* * *} \\
{[4.08]}\end{array}$ & & & & \\
\hline Log of Tier 1 Capital & & & & & $\begin{array}{r}1.885 * * * \\
{[2.46]}\end{array}$ & $\begin{array}{r}1.437 * * * \\
{[5.29]}\end{array}$ & $\begin{array}{r}1.327 * * * \\
{[6.75]}\end{array}$ & $\begin{array}{r}1.389 * * * \\
{[5.89]}\end{array}$ \\
\hline Obs. & 25 & 25 & 25 & 25 & 25 & 25 & 25 & 25 \\
\hline Adj. R-squared & 0.000 & 0.035 & 0.418 & 0.194 & 0.000 & 0.395 & 0.608 & 0.495 \\
\hline F statistics (of first stage) & 1.49 & 2.71 & 3.78 & 3.10 & 2.05 & 2.50 & 3.04 & 2.73 \\
\hline
\end{tabular}




\section{Table 10: Operating Performance prior to the Crisis}

Reported are panel regressions for three measures of operating performance over the period 1998-2006. Return on book assets is defined as the ratio of annual operating profits before taxes and a bank's book assets, return on book equity is calculate as the ratio of annual operating profits before taxes and book equity, and per capita profit measures annual operating profits (in $\mathrm{m}$. €) relative to the number of bank employees. The explanatory variables are a dummy coded 1 for private banks and 0 for state banks, the average finance experience (AIF) measure of the supervisory board and its aggregate total experience measure (AIT). The regressions allow for random effects for each year and each bank. Fixed time effects yield similar results. The t-values of the coefficients are reported in brackets. We mark statistical significance at the 10 percent level $(*)$, the 5 percent level $(* *)$ and the 3 percent level $(* * *)$.

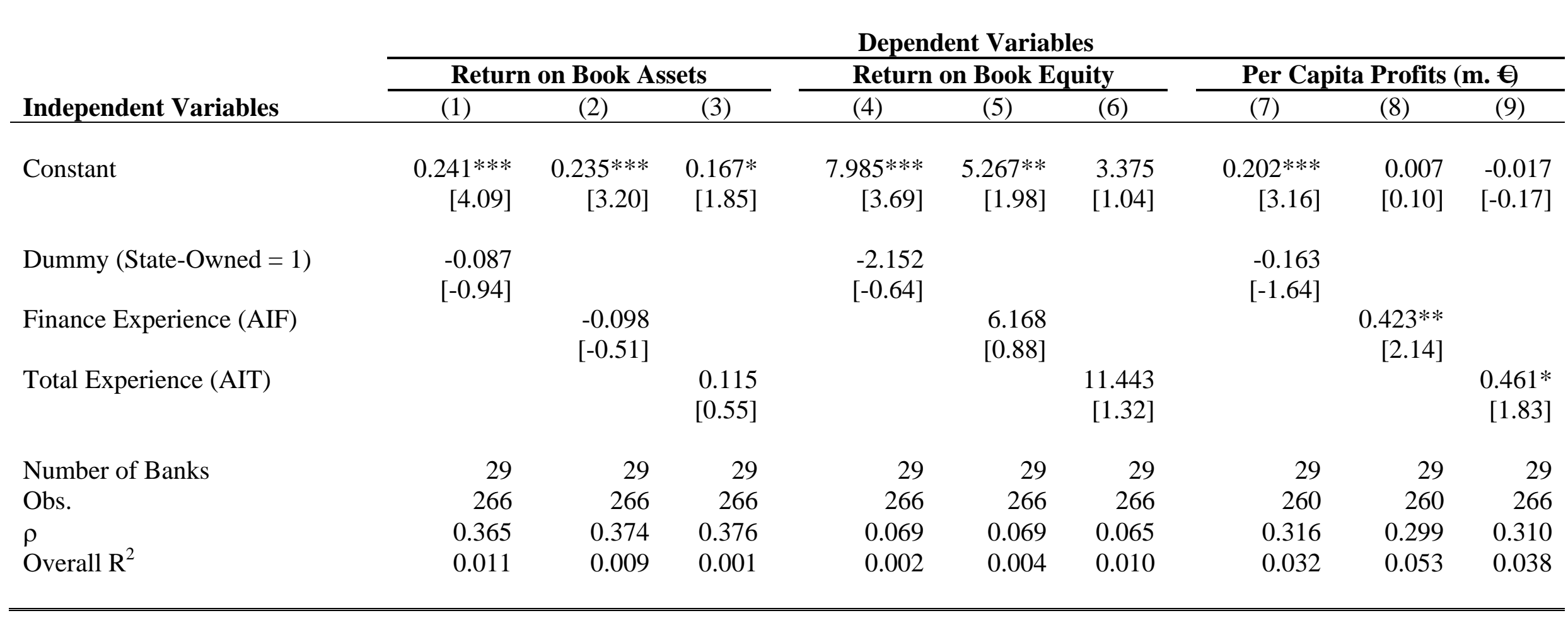

Source: Authors’ calculation 


\section{Table 11: Determinants of Executive Pay}

The dependent variable in the OLS regressions is the log of the average compensation of 25 German bank executive boards in 2006. The explanatory variables are a dummy coded 1 for private banks and 0 for state banks, the percentage of politically appointed supervisory board members (Political Affiliations), the average finance experience (AIF) measure of the supervisory board and its aggregate total experience measure $(\mathrm{AIT})$. The $\mathrm{t}$-values of the coefficients are reported in brackets. We mark statistical significance at the 10 percent level $(*)$, the 5 percent level $(* *)$ and the 3 percent level $(* * *)$.

\begin{tabular}{|c|c|c|c|c|}
\hline \multirow[b]{2}{*}{ Independent Variables } & \multicolumn{4}{|c|}{ Dependent Variable: Log of Executive Pay } \\
\hline & $(1)$ & $(2)$ & $(3)$ & $(4)$ \\
\hline Constant & $\begin{array}{r}-0.796 * * * \\
{[-2.20]}\end{array}$ & $\begin{array}{r}-0.767 * * * \\
{[-2.40]}\end{array}$ & $\begin{array}{r}-0.901 * * * \\
{[-2.58]}\end{array}$ & $\begin{array}{r}-0.947 * * * \\
{[-2.93]}\end{array}$ \\
\hline Log of Total Assets & $\begin{array}{r}0.300^{* * *} \\
{[4.57]}\end{array}$ & $\begin{array}{r}0.308 * * * \\
{[5.19]}\end{array}$ & $\begin{array}{r}0.300 * * * \\
{[4.56]}\end{array}$ & $\begin{array}{r}0.291 * * * \\
\text { [4.47] }\end{array}$ \\
\hline Dummy (State Owned = 1) & $\begin{array}{l}-0.095 \\
{[-0.77]}\end{array}$ & & & \\
\hline Political Affiliations & & $\begin{array}{r}-0.612 * * \\
{[-2.33]}\end{array}$ & & \\
\hline Finance Experience (AIF) & & & $\begin{array}{r}0.106 \\
{[0.72]}\end{array}$ & \\
\hline Total Experience (AIT) & & & & $\begin{array}{r}0.155 \\
{[1.27]}\end{array}$ \\
\hline $\begin{array}{l}\text { Obs. } \\
\text { Adj. } R^{2}\end{array}$ & $\begin{array}{r}26 \\
0.452\end{array}$ & $\begin{array}{r}26 \\
0.546\end{array}$ & $\begin{array}{r}26 \\
0.450\end{array}$ & $\begin{array}{r}26 \\
0.475\end{array}$ \\
\hline
\end{tabular}

Source: Authors' calculation 


\section{Table 12: Absolute Bank Losses and Executive Pay}

Reported are OLS regressions for the (log of the) bank losses in the period 2007-2008 for 25 German banks. As the independent variables we use the log of the average compensation of a bank's management board member, as well as supervisory board competence measures, namely its average finance experience (AIF) and the aggregate total experience measure (AIT). Each regression controls for the bank size by using (the log of) the total bank assets. The t-values of the coefficients are reported in brackets. We mark statistical significance at the 10 percent level $(*)$, the 5 percent level $(* *)$ and the 3 percent level $(* * *)$.

\begin{tabular}{|c|c|c|c|c|c|}
\hline \multirow[b]{2}{*}{ Independent Variables } & \multicolumn{5}{|c|}{ Dependent Variable: log(Loss) } \\
\hline & (1) & $(2)$ & $(3)$ & $(4)$ & (5) \\
\hline Constant & $\begin{array}{r}-4.950 * * * \\
{[-3.35]}\end{array}$ & $\begin{array}{r}-5.606 * * * \\
{[-5.00]}\end{array}$ & $\begin{array}{r}-4.705^{* * *} \\
{[-3.73]}\end{array}$ & $\begin{array}{r}-5.262 * * * \\
{[-4.39]}\end{array}$ & $\begin{array}{l}-4.380 \\
{[-3.21]}\end{array}$ \\
\hline Log of Executive Pay & $\begin{array}{c}0.833 \\
{[1.09]}\end{array}$ & & $\begin{array}{r}1.229 * \\
{[1.84]}\end{array}$ & & $\begin{array}{r}1.366^{*} \\
{[1.86]}\end{array}$ \\
\hline Finance Experience (AIF) & & $\begin{array}{r}-1.224 * * * \\
{[-2.41]}\end{array}$ & $\begin{array}{r}-1.486^{* * *} \\
{[-2.91]}\end{array}$ & & \\
\hline Total Experience (AIT) & & & & $\begin{array}{r}-0.658 \\
{[-1.43]}\end{array}$ & $\begin{array}{r}-1.084 * * \\
{[-2.29]}\end{array}$ \\
\hline Log of Total Assets & $\begin{array}{r}0.831^{* * *} \\
{[2.49]}\end{array}$ & $\begin{array}{r}1.190 * * * \\
{[5.39]}\end{array}$ & $\begin{array}{r}-0.871^{* * * *} \\
{[-3.06]}\end{array}$ & $\begin{array}{r}1.129 * * * \\
{[4.75]}\end{array}$ & $\begin{array}{r}0.842^{* * *} \\
{[2.78]}\end{array}$ \\
\hline $\begin{array}{l}\text { Obs. } \\
\text { Adj. } \mathrm{R}^{2}\end{array}$ & $\begin{array}{r}23 \\
0.440\end{array}$ & $\begin{array}{r}25 \\
0.535\end{array}$ & $\begin{array}{r}23 \\
0.593\end{array}$ & $\begin{array}{r}25 \\
0.462\end{array}$ & $\begin{array}{r}23 \\
0.538\end{array}$ \\
\hline
\end{tabular}

Source: Authors' calculation 


\section{CESifo Working Paper Series}

for full list see www.cesifo-group.org/wp

(address: Poschingerstr. 5, 81679 Munich, Germany, office@cesifo.de)

2577 Giorgio Bellettini and Filippo Taddei, Real Estate Prices and the Importance of Bequest Taxation, March 2009

2578 Annette Bergemann and Regina T. Riphahn, Female Labor Supply and Parental Leave Benefits - The Causal Effect of Paying Higher Transfers for a Shorter Period of Time, March 2009

2579 Thomas Eichner and Rüdiger Pethig, EU-Type Carbon Emissions Trade and the Distributional Impact of Overlapping Emissions Taxes, March 2009

2580 Antonios Antypas, Guglielmo Maria Caporale, Nikolaos Kourogenis and Nikitas Pittis, Selectivity, Market Timing and the Morningstar Star-Rating System, March 2009

2581 António Afonso and Christophe Rault, Bootstrap Panel Granger-Causality between Government Budget and External Deficits for the EU, March 2009

2582 Bernd Süssmuth, Malte Heyne and Wolfgang Maennig, Induced Civic Pride and Integration, March 2009

2583 Martin Peitz and Markus Reisinger, Indirect Taxation in Vertical Oligopoly, March 2009

2584 Petra M. Geraats, Trends in Monetary Policy Transparency, March 2009

2585 Johannes Abeler, Armin Falk, Lorenz Götte and David Huffman, Reference Points and Effort Provision, March 2009

2586 Wolfram F. Richter, Taxing Education in Ramsey’s Tradition, March 2009

2587 Yin-Wong Cheung, Menzie D. Chinn and Eiji Fujii, China's Current Account and Exchange Rate, March 2009

2588 Alexander Haupt and Silke Uebelmesser, Voting on Labour-Market Integration and Education Policy when Citizens Differ in Mobility and Ability, March 2009

2589 Hans Jarle Kind, Marko Koethenbuerger and Guttorm Schjelderup, Should UtilityReducing Media Advertising be Taxed?, March 2009

2590 Alessandro Cigno, How to Avoid a Pension Crisis: A Question of Intelligent System Design, March 2009

2591 Helmut Lütkepohl and Fang Xu, The Role of the Log Transformation in Forecasting Economic Variables, March 2009 
2592 Rainald Borck, Hyun-Ju Koh and Michael Pflüger, Inefficient Lock-in and Subsidy Competition, March 2009

2593 Paolo M. Panteghini, On the Equivalence between Labor and Consumption Taxation, March 2009

2594 Bruno S. Frey, Economists in the PITS?, March 2009

2595 Natalie Chen and Dennis Novy, International Trade Integration: A Disaggregated Approach, March 2009

2596 Frédérique Bec and Christian Gollier, Term Structure and Cyclicity of Value-at-Risk: Consequences for the Solvency Capital Requirement, March 2009

2597 Carsten Eckel, International Trade and Retailing, March 2009

2598 Gianni De Nicolò and Iryna Ivaschenko, Global Liquidity, Risk Premiums and Growth Opportunities, March 2009

2599 Jay Pil Choi and Heiko Gerlach, International Antitrust Enforcement and Multi-Market Contact, March 2009

2600 Massimo Bordignon and Guido Tabellini, Moderating Political Extremism: Single Round vs Runoff Elections under Plurality Rule, April 2009

2601 Ana B. Ania and Andreas Wagener, The Open Method of Coordination (OMC) as an Evolutionary Learning Process, April 2009

2602 Simon Gächter, Daniele Nosenzo, Elke Renner and Martin Sefton, Sequential versus Simultaneous Contributions to Public Goods: Experimental Evidence, April 2009

2603 Philippe Jehiel and Andrew Lilico, Smoking Today and Stopping Tomorrow: A Limited Foresight Perspective, April 2009

2604 Andreas Knabe, Steffen Rätzel, Ronnie Schöb and Joachim Weimann, Dissatisfied with Life, but Having a Good Day: Time-Use and Well-Being of the Unemployed, April 2009

2605 David Bartolini and Raffaella Santolini, Fiscal Rules and the Opportunistic Behaviour of the Incumbent Politician: Evidence from Italian Municipalities, April 2009

2606 Erkki Koskela and Jan König, Can Profit Sharing Lower Flexible Outsourcing? A Note, April 2009

2607 Michel Beine, Frédéric Docquier and Çağlar Özden, Diasporas, April 2009

2608 Gerd Ronning and Hans Schneeweiss, Panel Regression with Random Noise, April 2009 
2609 Adam S. Booij, Bernard M.S. van Praag and Gijs van de Kuilen, A Parametric Analysis of Prospect Theory's Functionals for the General Population, April 2009

2610 Jeffrey R. Brown, Julia Lynn Coronado and Don Fullerton, Is Social Security Part of the Social Safety Net?, April 2009

2611 Ali Bayar and Bram Smeets, Economic, Political and Institutional Determinants of Budget Deficits in the European Union, April 2009

2612 Balázs Égert, The Impact of Monetary and Commodity Fundamentals, Macro News and Central Bank Communication on the Exchange Rate: Evidence from South Africa, April 2009

2613 Michael Melvin, Christian Saborowski, Michael Sager and Mark P. Taylor, Bank of England Interest Rate Announcements and the Foreign Exchange Market, April 2009

2614 Marie-Louise Leroux, Pierre Pestieau and Gregory Ponthiere, Should we Subsidize Longevity?, April 2009

2615 Ronald MacDonald, Lukas Menkhoff and Rafael R. Rebitzky, Exchange Rate Forecasters' Performance: Evidence of Skill?, April 2009

2616 Frederick van der Ploeg and Steven Poelhekke, The Volatility Curse: Revisiting the Paradox of Plenty, April 2009

2617 Axel Dreher, Peter Nunnenkamp, Hannes Öhler and Johannes Weisser, Acting Autonomously or Mimicking the State and Peers? A Panel Tobit Analysis of Financial Dependence and Aid Allocation by Swiss NGOs, April 2009

2618 Guglielmo Maria Caporale, Roman Matousek and Chris Stewart, Rating Assignments: Lessons from International Banks, April 2009

2619 Paul Belleflamme and Martin Peitz, Asymmetric Information and Overinvestment in Quality, April 2009

2620 Thomas Dohmen, Armin Falk, David Huffman and Uwe Sunde, Are Risk Aversion and Impatience Related to Cognitive Ability?, April 2009

2621 Yin-Wong Cheung and Xingwang Qian, The Empirics of China's Outward Direct Investment, April 2009

2622 Frédérique Bec and Christian Gollier, Assets Returns Volatility and Investment Horizon: The French Case, April 2009

2623 Ronnie Schöb and Marcel Thum, Asymmetric Information Renders Minimum Wages Less Harmful, April 2009

2624 Martin Ruf and Alfons J. Weichenrieder, The Taxation of Passive Foreign Investment Lessons from German Experience, April 2009 
2625 Yao Li, Borders and Distance in Knowledge Spillovers: Dying over Time or Dying with Age? - Evidence from Patent Citations, April 2009

2626 Jim Malley and Ulrich Woitek, Technology Shocks and Aggregate Fluctuations in an Estimated Hybrid RBC Model, April 2009

2627 Jin Cao and Gerhard Illing, Endogenous Systemic Liquidity Risk, April 2009

2628 Thiess Buettner and Bjoern Kauder, Revenue Forecasting Practices: Differences across Countries and Consequences for Forecasting Performance, April 2009

2629 Håkan Selin, The Rise in Female Employment and the Role of Tax Incentives - An Empirical Analysis of the Swedish Individual Tax Reform of 1971, April 2009

2630 Nick Johnstone and Ivan Hascic, Environmental Policy Design and the Fragmentation of International Markets for Innovation, April 2009

2631 Spiros Bougheas, Richard Kneller and Raymond Riezman, Optimal Education Policies and Comparative Advantage, April 2009

2632 Jay Pil Choi and Heiko Gerlach, Multi-Market Collusion with Demand Linkages and Antitrust Enforcement, April 2009

2633 Thor O. Thoresen, Income Mobility of Owners of Small Businesses when Boundaries between Occupations are Vague, April 2009

2634 Guido Schwerdt and Amelie C. Wuppermann, Is Traditional Teaching really all that Bad? A Within-Student Between-Subject Approach, April 2009

2635 Kurt R. Brekke, Luigi Siciliani and Odd Rune Straume, Hospital Competition and Quality with Regulated Prices, April 2009

2636 Peter Diamond, Taxes and Pensions, April 2009

2637 Shoshana Grossbard, How "Chicagoan” are Gary Becker's Economic Models of Marriage?, May 2009

2638 Roland Strausz, Regulatory Risk under Optimal Incentive Regulation, May 2009

2639 Holger Zemanek, Ansgar Belke and Gunther Schnabl, Current Account Imbalances and Structural Adjustment in the Euro Area: How to Rebalance Competitiveness, May 2009

2640 Harald Hau and Marcel Thum, Subprime Crisis and Board (In-)Competence: Private vs. Public Banks in Germany, May 2009 